\title{
Eemian Lake development, hydrology and climate: a multi-stratigraphic study of the Hollerup site in Denmark
}

\author{
Svante Björck ${ }^{\mathrm{a}, *}$, Nanna Noe-Nygaard ${ }^{\mathrm{a}}$, Julie Wolin ${ }^{\mathrm{b}}$, Michael Houmark-Nielsen ${ }^{\mathrm{a}}$, \\ Hans Jørgen Hansen ${ }^{a}$, Ian Snowball ${ }^{\mathrm{c}}$ \\ ${ }^{a}$ Geological Institute, Øster Voldgade 10, DK-1350 Copenhagen K, Denmark \\ ${ }^{\mathrm{b}}$ Department of Biology, Indiana University of Pennsylvania, Indiana, PA 15705, USA \\ 'Department of Quaternary Geology, Lund University, Tornav. 13, S-223 63 Lund, Sweden
}

\begin{abstract}
A classic northwest European open section with lacustrine Eemian sediments, Hollerup, has been studied with respect to sedimentology, geochemistry, stable isotopes, diatoms and mineral magnetic analyses, and correlated by geochemistry and diatoms to a previously pollen analysed section by Andersen (1965). This correlation has enabled the section to be related to Müller's (1974) tentative Eemian absolute chronology, and shows that the Hollerup Eemian sediments appear to cover c. 11,000 yr. Our studies show that the onset of the Eemian was characterized by a major lake level rise followed by an almost $3000 \mathrm{yr}$ long period of high, but oscillating lake levels. It is argued that the latter part of this period of highly maritime climate can be defined as the Eemian climatic optimum. This period was interrupted by a few hundred years long phase of low lake level, coinciding with the immigration of spruce, followed by medium-high lake levels. The next c. $3500 \mathrm{yr}$, coinciding with the Carpinus pollen zone, seem to have been characterized by fairly humid and mild conditions, although slightly more arid than during the preceding optimum. The Carpinus period ended with a more than $1000 \mathrm{yr}$ long gradual lake level fall, and this period of lake level change, concurring with the transition into the Pinus pollen dominated period, terminated with an extreme low lake level event. This 300-500 yr long arid phase coincides with a distinct peak in pine pollen, and was followed by higher but slightly oscillating lake levels in a cooler climate. The end of the Eemian seems to have been characterised by a gradual cooling, until almost pure clastic sedimentation and a marked expansion of herb pollen grains mark the onset of the Weichselian. Based on regional correlations to other European terrestrial and North Atlantic marine proxy records, we argue that the distinct hydrologic and climatic events displayed in the Hollerup record were possibly caused by a combination of sea level changes, changes in the hydrologic cycle and changing oceanic circulation patterns. The latter two may have been triggered by the opening and closure of the Baltic Sea-White Sea connection, the initial build-up of continental ice sheets, and the first major impacts of meltwater induced freshwater in key areas for thermohaline circulation. (C) 2000 Elsevier Science Ltd. All rights reserved.
\end{abstract}

\section{Introduction}

The discussion concerning a climatically stable or unstable Eemian has mainly focussed on conflicting ice core records (McManus et al., 1994), opposing views on how to interpret and/or model pollen records (e.g. Field et al., 1994; Litt et al., 1996) and geographically spread marine records (e.g. Cortijo et al., 1994; Sejrup et al., 1995; Seidenkrantz et al., 1995; Seidenkrantz and Knudsen 1997; Fronval and

\footnotetext{
* Corresponding author. Tel.: + 45-35-32-26-26; fax: + 45-35-3224-99.

E-mail address: svante@geo.geol.ku.dk (S. Björck).
}

Jansen, 1996, 1997; Adkins et al., 1997). Here we report the results of a multi-proxy study of lacustrine sediments from the classic Danish Eemian site of Hollerup (Jessen and Milthers, 1928; Andersen, 1965, 1966). Our study is based on detailed sediment descriptions, high-resolution mineral magnetic analyses, carbon and carbonate analyses, stable isotope measurements $\left({ }^{13} \mathrm{C}\right.$ and $\left.{ }^{18} \mathrm{O}\right)$, measurements of fat acids and diatom analyses. Based on lithologic/geochemical correlations to Andersen's (1965) pollen study it is possible to relate our data set to the Eemian vegetation history of Denmark. This allows the relation of our data to vegetational development and also to the tentative lacustrine Eemian chronology of Müller (1974). 


\section{Site description and geological setting}

The Eemian site of Hollerup is situated on the northern edge of the Gudenå valley $\left(56^{\circ} 24^{\prime} 23^{\prime \prime} \mathrm{N}, 9^{\circ} 50^{\prime} 46^{\prime \prime} \mathrm{E}\right)$, $14 \mathrm{~km}$ southeast of Randers, between Langå and Ulstrup, in the eastern part of central Jylland (Fig. 1). It consists of a poorly preserved section of a former diatomaceous earth pit. Diatomaceous lake deposits are present in well-logs elsewhere in the area and they probably all belong to the Eemian interglacial, though they may represent separate lake basins (DGU, 1991). The interglacial deposits at Hollerup are sandwiched between fluvial and glaciogenic deposits (Fig. 2). Glaciofluvial sand and gravel rich in Cretaceous and Danian limestone, overlying the Saalian till, constitute the substratum for the Hollerup deposits. The glaciofluvial deposits, covering the lacustrine sediments, are overlain by well-sorted and bedded Early Weichselian sand and a Late Weichselian till (Kronborg et al., 1990). The underlying bedrock in the surroundings of the site consists of Oligocene and early Miocene mica-rich clays.

Studies of the macro flora and fauna, as well as diatoms were first published by Hartz and Østrup (1899). They concluded that the lake environment was of an interglacial nature and that the diatom flora of Hollerup is comparable to that of present Danish lakes. Jessen and Milther's (1928) pollen study was the first to describe the floristic evolution, and later Andersen's (1965) modern pollen analyses gave a fairly detailed picture of the regional Eemian vegetation development. The main floristic changes were assigned to changes in soil development, while the large pollen stratigraphic change at the top of the section, with a distinct increase in herb and shrub pollen grains, was related to the beginning of the Weichselian cooling. He also showed that the site has a pollen signature (e.g. Carpinus and Taxus) typical for NW European Eemian sites, and was easy to correlate to previously studied sites in Germany and Holland. Some attempts have been made to prescribe an absolute age to the Hollerup sediments. Kronborg and Mejdahl (1989) TL-dated the Hollerup diatomite to $88 \mathrm{ka}$, which with a shallow trap correction (Mejdahl and Funder, 1994) would result in an age of $120 \mathrm{ka}$, and the Israelson et al., (1998) uranium-series datings of the diatomaceous gyttja gave ages between 89 and 199 ka.

The main section studied by us consists of an almost $5 \mathrm{~m}$ thick profile of lacustrine sediments (Figs. 2 and 3A and $\mathrm{B}$ ), situated in a slightly more near-shore environment than the $6.3 \mathrm{~m}$ (Jessen and Milthers, 1928) and $8.5 \mathrm{~m}$ (Andersen, 1965) sections previously studied. The original lake is assumed to have had dimensions of at least $200 \times 250 \mathrm{~m}$, but most of its sediment has been excavated.

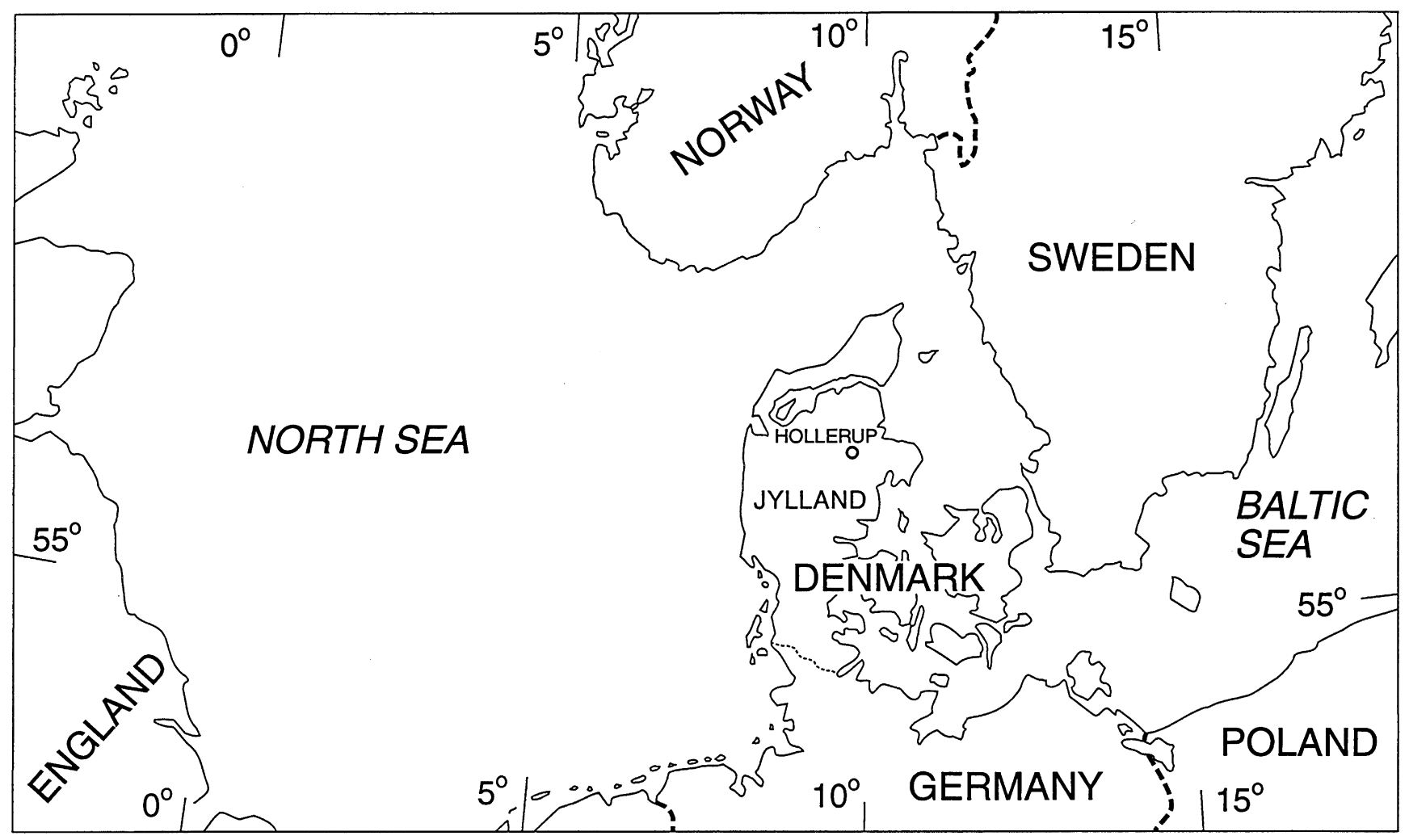

Fig. 1. Map of NW Europe and Denmark, including the position of the Hollerup site. 


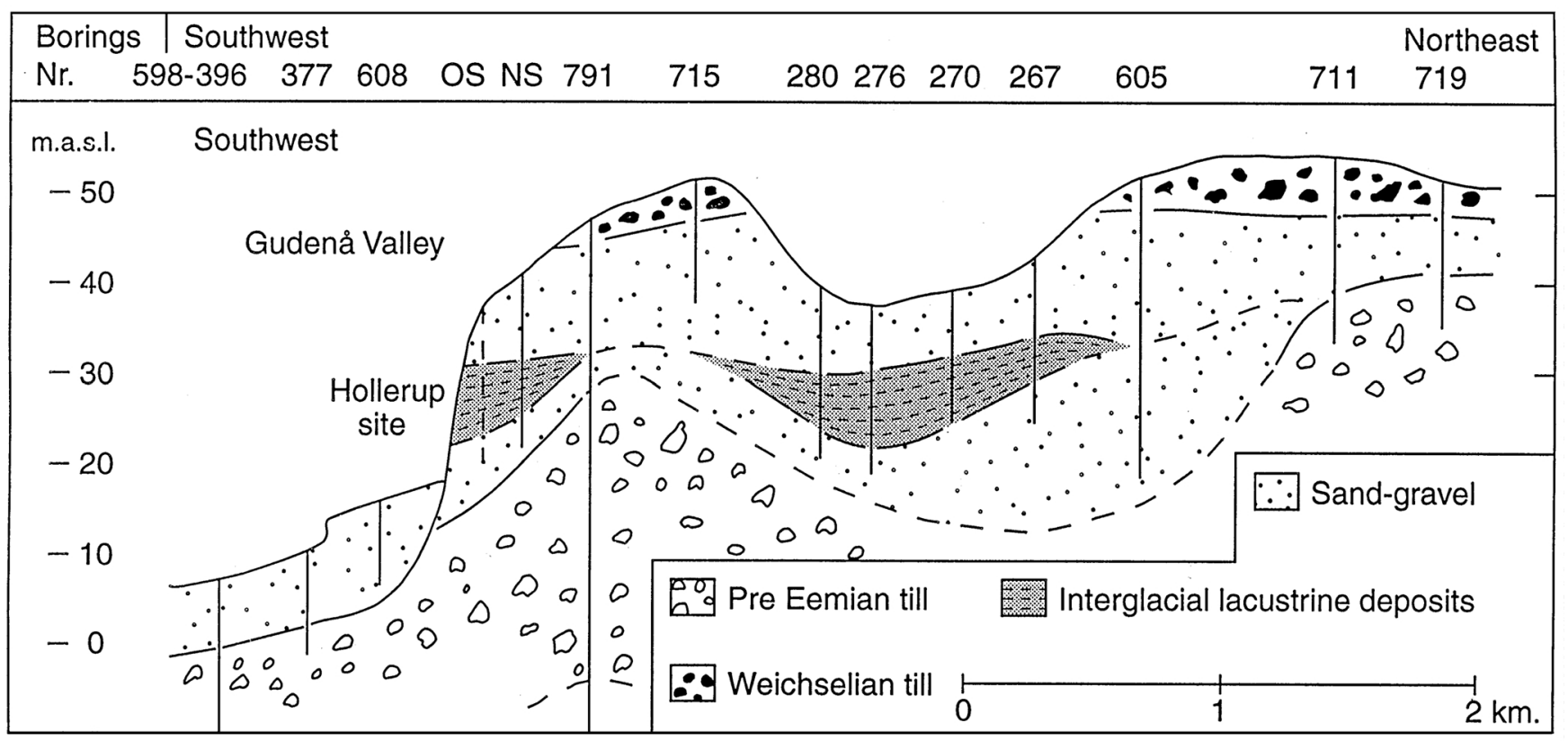

Fig. 2. Section through the Quaternary deposits on the northeastern flank of the Gudenå Valley, showing the stratigraphic position of the Hollerup lake sediments, and the borings upon which the stratigraphy is based. The wedge-shaped occurrence of the sediments explains why the old sections (OS) were thicker than the presently exposed section (NS).

\section{Methods}

\subsection{Field work}

The site was visited on several occasions and each time the section was carefully cleaned, which means that during the course of the study we have worked a few metres into the section. The first field work comprised very detailed sampling as well as a preliminary sediment description. The section was contigously sampled at $1 \mathrm{~cm}$ intervals in $10-15 \mathrm{~cm}^{3}$ large samples for geomagnetic and any other relevant paleoenvironmental analyses. When the magnetic results showed very distinct changes it was decided to enlarge the study into a multi-parameter investigation of the section. This was complemented by sediment logging and facies description at different occasions, which revealed lateral facies changes. The description, nomenclature and signature of the sediments follow Troels-Smith (1955) and Noe-Nygaard (1995).

\subsection{Laboratory methods}

\subsubsection{Carbon and carbonate analyses}

After freeze-drying, the total carbon content (TC) was measured in a Metalyt $90 \mathrm{~S}$ furnace and the $\mathrm{CaCO}_{3}$ content was determined by titration. The content of total organic carbon (TOC) was calculated as $\mathrm{TOC}=\mathrm{TC}$ $\left(12 / 100 \times \mathrm{CaCO}_{3}\right)$, while amount of organic matter was estimated as TOC $\times 2.5$. The mineral residue (including diatom silica) is that left after reduction of organic matter and $\mathrm{CaCO}_{3}$.

\subsubsection{Organic geochemical analyses}

Samples were extracted using a Soxtec apparatus at the Geological Survey of Denmark and Greenland, followed by MPLC fractionation. Fatty acids were methylated to fatty acid methyl esters. The aliphatic and the methyl esters were analysed on a HP 5890 II gas chromatograph.

\subsubsection{Stable isotope analyses}

After freeze-drying, carbon and oxygen isotope analysis was performed on $\mathrm{CO}_{2}$ gas derived from two different preparation lines. Bulk organic material was analysed for stable carbon isotopes and the samples were decarbonated before combustion at $900^{\circ} \mathrm{C}$ in a stream of oxygen. Carbonate sediment samples were analysed for stable carbon and oxygen isotopes after a preparation line described by Buchardt (1977). The cryogenically trapped and purified $\mathrm{CO}_{2}$ from both organic and carbonate samples was analysed on a Finnigan-MAT 250 mass-spectometer at the stable isotope laboratory, Geological Institute in Copenhagen. The reproducibility of all analyses is less than $\pm 0.07 \%$. Results are expressed as conventional $\delta$-values $(\%$ deviations from the international PDB standard (Craig, 1957)).

\subsubsection{Mineral magnetic analyses}

Subsamples of the bulk sediment samples (collected at $1 \mathrm{~cm}$ intervals) were packed firmly into non-magnetic plastic boxes (internal volume of $7 \mathrm{~cm}^{3}$ ) and freeze-dried, and the mass of the dry sediment was determined to allow the calculation of mass specific SI units. Initial 

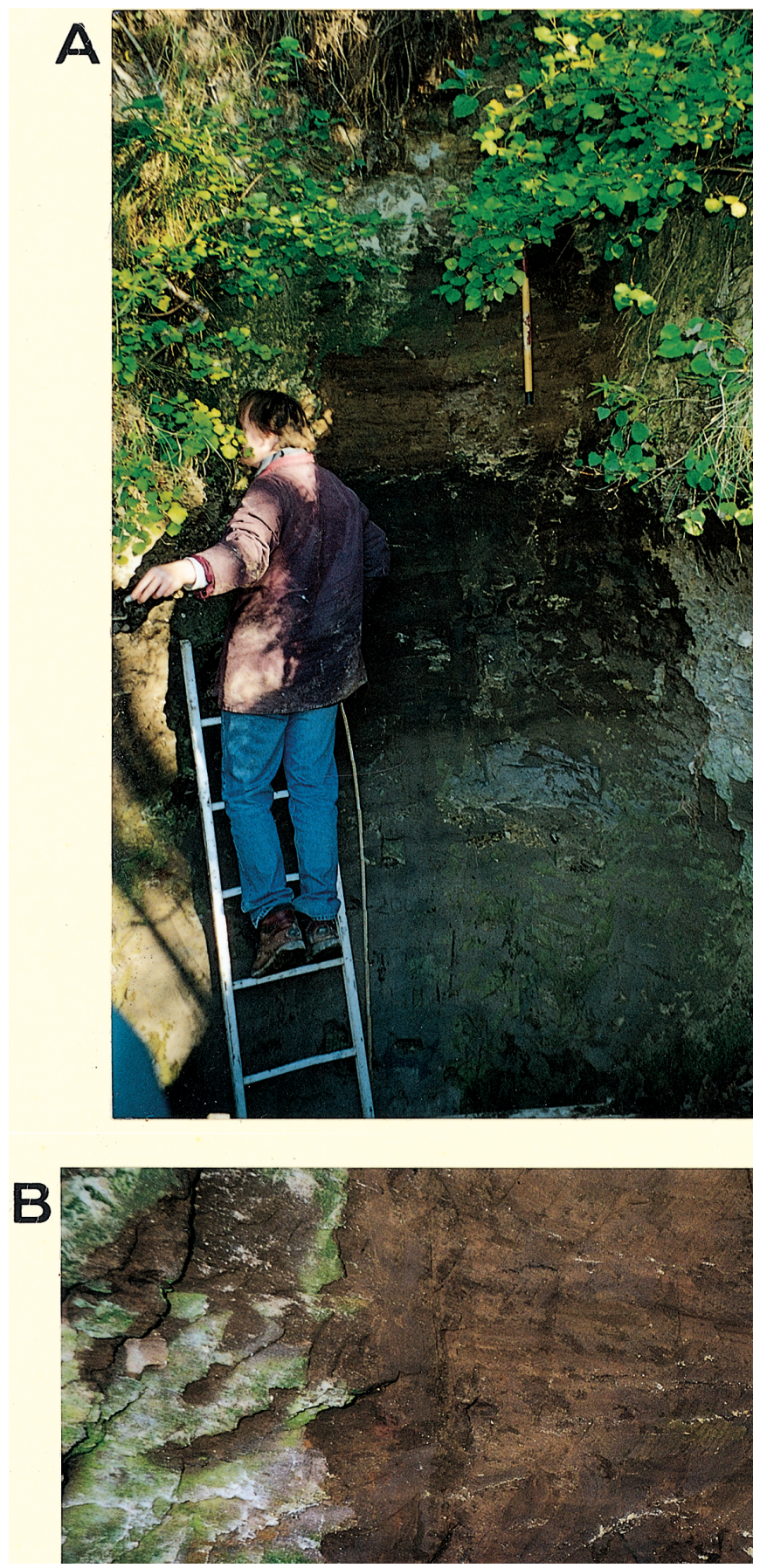

Fig. 3. (A) Photos of the three main sediment successions at Hollerup. The lowermost grey unit is the lime mud facies association, the black unit is the fine calcareous detritus gyttja facies association and the upper brown sediments correspond to the diatom-rich gyttja facies association (note the man for scale). (B) The transition between the fine algae detritus gyttja and the more or less pure diatomite, which corresponds to the sediment boundary at $120 \mathrm{~cm}$ in the $\log$ (see Fig. 4). The broken and desiccated greenish algae gyttja is interpreted as indicating low water level or even subarial exposure (see text for detailed discussion).

magnetic susceptibility $(\chi)$ was measured with a Geofyzica Brno KLY-2 Kappa bridge. Saturation isothermal remanent magnetization (SIRM) at 1 Tesla (T) and a backfield of $100 \mathrm{mT}$ were induced with a Redcliff
BSM-700 pulse magnetizer, and all the magnetic remanences were measured with a Molspin Minispin magnetometer. Samples representative of the different magnetic units identified were selected for more detailed analyses according to the diagnostic methods outlined by Oldfield (1994) and Snowball (1997). For these measurements the samples were repacked. The frequency dependence of initial magnetic susceptibility $\left(\chi_{\mathrm{FD}}\right)$ was determined with a Bartington MS2 susceptibility meter and susceptibility bridge (MS2B) operating at frequencies of 0.4665 and $4.65 \mathrm{kHz}$. Anhysteretic remanent magnetization (ARM) was induced in a peak alternating field (AF) of $100 \mathrm{mT}$, with a direct bias field of $0.1 \mathrm{mT}$. A converted Molspin AF demagnetizer was used to impart rotational remanent magnetization (RRM) at a peak AF of $100 \mathrm{mT}$ at a rotation rate of $5 \mathrm{rps}$, and also to demagnetize the induced RRM at $10 \mathrm{mT}$ intervals up to a peak $\mathrm{AF}$ of $100 \mathrm{mT}$. The effective gyro field $(\mathrm{Bg})$ induced in the samples was calculated according to Potter and Stephenson (1986). Detailed results of the RRM analyses were presented in Snowball (1997).

\subsubsection{Diatom analyses}

Subsamples for diatom analysis were taken from our Hollerup section in 1995 and from archived samples collected by Andersen in 1961, which were originally subjected to pollen analyses (Andersen, 1965). Sample preparation followed standard techniques: carbonate dissolution by $\mathrm{HCl}$ followed by oxidation of organic matter with $\mathrm{H}_{2} \mathrm{O}_{2}$ and rinsing repeatedly with distilled water (Battarbee, 1986). Diatom samples from $150-270 \mathrm{~cm}$ in the 1995 section were mounted in Microps 137, all other samples were mounted in Naphrax $\AA$. Diatom valves, chrysophycean cysts and sponge spicules were counted in transects with a Leitz Ortholux microscope at $1200 \times$ magnification under oil immersion. A minimum of 500 diatom valves were counted in each sample, except for samples where diatom concentrations were very low. In these cases, a minimum of four transects were counted.

A total of 91 samples were analysed from our new section at $5 \mathrm{~cm}$ intervals, with the exception of samples between $150-170 \mathrm{~cm}$ and $170-240$, which were counted in 2 and $10 \mathrm{~cm}$ intervals, respectively.

Changes in $\mathrm{pH}$ and nutrient conditions during lake development were determined by numerical methods. Diatom inferred $\mathrm{pH}$ values were estimated using the new $\mathrm{pH}$ formula (NEW $\mathrm{pH}$ ) and the new multiple regression equation (MR pH) developed by Håkansson (1993). These methods were developed for use in lakes of circum-neutral $\mathrm{pH}$. Both methods were based on $\mathrm{pH}$ and surface-sediment diatom data from 24 southern Swedish and Finnish lakes. Weighted averaging regression and calibration methods for $\mathrm{pH}$ reconstruction (Birks et al., 1990) were not used as no appropriate calibration set is currently available for circum-neutral systems. Diatom taxa were categorized by $\mathrm{pH}$ for indifferent (IND), 
alkaliphilous (AKP), and alkalibiontic (AKB) groups according to the designations published by Håkansson (1993). Only a few valves of acidophilic taxa were found in all samples analysed and no acidobiontic taxa were present. Equations for the new $\mathrm{pH}$ formula were derived by fitting normal probability curves to the percentages of the diatom $\mathrm{pH}$ groups from the 24 lake data set plotted as a function of lake $\mathrm{pH}$.

Diatom-inferred total phosphorus (TP) concentrations were explored utilizing published TP optima from Bennion (1994), Fritz et al., (1993) and Reavie et al., (1995). However, reconstructions using these data sets were problematic. Optima from Bennion's data set are based on hypereutrophic shallow lakes in southeastern England and are biased towards a high TP range. Additionally, many of the taxa present early in the history of the Hollerup site were not present in Bennion's data set. To remedy this problem, optima from two North American data sets (Fritz et al., 1993; Reavie et al., 1995) were utilized. These data sets have the advantage of containing a higher number of analogue taxa. Data sets from North America represent nutrient conditions that more closely approximate those of the Eemian, since in most cases human impact is relatively low in the regions where these sets were developed. However, optima from these data, are biased towards a low TP range and may underestimate values for the upper samples.

\subsubsection{Multivariate analysis}

The CANOCO programme (Ter Braak, 1988) was used to analyse parts of the large data set with multivariate statistical techniques. Diatom zones were determined by running detrended correspondence analysis (DCA) on the data using taxa which occur with more than $1 \%$ in all samples.

In order to analyse and zonate the overall development of the section the following 10 variables were selected for further multivariate analysis: carbonate, organic and mineral matter (incl. diatom opal), magnetic susceptibility, SIRM, HIRM, S-ratio, $\delta^{13} C_{\text {org }}$, diatom inferred $\mathrm{pH}$ and percentage of planktonic diatoms. The variables must fulfill three conditions: they should have been measured throughout most of the section, values must be positive, and they should vary between 0.1 and $<1000$. For the latter reasons the negative $\delta^{13} \mathrm{C}_{\text {org }}$ values were regarded as positive, i.e. the position of $\delta^{13} C_{\text {org }}$ in the statistical plots relates to high negative values, the $\mathrm{S}$-ratio values were added with +1 , i.e. the position of S-ratio in the plots relates to low negative S-ratios (haematite/goethite), and the susceptibility, SIRM and HIRM values were multiplied by 100 . These ten variables in 55 samples were analysed with DCA (detrending by segments), which gave a gradient length $>2$. This shows that correspondence analysis (CA) is used to better evaluate the interaction between variables and samples. However, since this mixture of data is expressed in different units and displays a very variable range, the data was $1 n$-transformed during the CA analysis.

\section{Results and interpretations}

\subsection{Facies description, sedimentology, lithostratigraphy and stable isotopes}

Apart from the under- and overlying gravels and sands, Andersen (1965) divided the section into four different units: a lake marl in the lower part, which gradually grades into a less carbonate-, but more organic-rich gyttja. This detritus gyttja in turn grades into a diatomaceous gyttja, which is overlain by a gradually more minerogenic clay gyttja. However, detailed studies of the sediments reveal a much higher degree of complexity than previously described and below follows a facies description (from bottom to top) with a sediment log (Fig. 4), as well as an interpretation of the depositional environment, including their stable isotope and geochemical signatures (Figs. 5 and 8). The lowermost sands and gravels with ironcrust were, however, only studied from a sedimentological viewpoint.

\subsubsection{The fining upwards clastic succession $(520-500 \mathrm{~cm})$}

The section starts with four $5 \mathrm{~cm}$ thick fining upwards cycles. The grain size ranges from very fine pebbles to medium sand in the lower cycles and from coarse to fine sand at the top. The upper transition into the "ironcrust impregnated coarsening upwards clastic bed" is irregular and sharp. No sediment strucures apart from grading were noted in these purely clastic sediments.

The pure clastic graded sediment, deposited as fining up cycles in an over all fining upwards succession, indicates sediment transport and supply in pulses by relatively strong currents. Deposition occurred in water from a non-vegetated environment presumably in a fairly shallow proglacial lake or on a melt-water flood plain.

\subsubsection{Unit 1: ironcrust impregnated coarsening upwards clastic facies $(500-487 \mathrm{~cm})$}

This coarse clastic facies is c. $13 \mathrm{~cm}$ thick and occurs in several profiles in the vicinity of the present exposure. It marks the change from predominantly clastic sediments to lacustrine carbonates and gyttjas. Its lower and upper boundaries are sharp and irregular and appear clearly erosive. This transition bed is indistinctly coarsening upward from coarse sand to fine cobbles. At the bottom slump structures occur. From the top of the layer limonite coated roots penetrate to depths of $5 \mathrm{~cm}$. Limonite also covers the larger clasts.

The weak inverse grading, slump structures and the sharp upper and lower boundary indicate rapid 
HOLLERUP

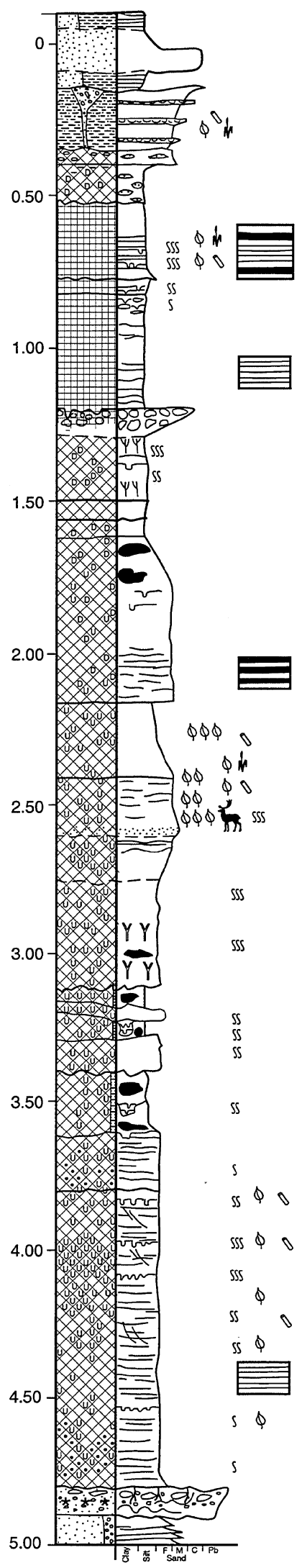

$1-2 \mathrm{~cm}$ long sand lenses in
clay gyttja.
Diatomite with abundant plant
macro fossils and bioturbation.
Light laminae $3 \mathrm{~cm}$.
Dark laminae $4-5 \mathrm{~mm}$.
Laminae thickness $3 \mathrm{~cm}$.

Blackies, brown, bioturbated strongly humified gyttia: Fish scales and stems.

Grey brown diatome rich fine detritus gyttja. Dark brown silty fine detritus gyttja. dark brown.

Towards the top increasingly occurrence of black spots.

Indistinct light and dark brown lamination. Scattered sand grains.

Brownish grey massive carbonate rich detritus gyttja with plant remains.

Many charred plant remains. Dark grey calcareous gyttja with medium sand grains at the bottom.

Transitional boundary. Indistinct laminae.

Transitional boundary.

Lime mud without any visible structures. Vertical carbonized plant stems.

Black anoxic mud pockets with trace fossils. The trace fossils probably occur in the
light beds, this can not be distinguished.

Black anoxic pockets with trace fossils a la Planolites.

Lime mud with affluent carbonized organic material. Upwards increasing humic staining. Bands of dark colour containing well preserved complete leaves of oak - better preservation in dark bands.

White flames.

Laminae thickness $2 \mathrm{~mm}$.

Lime mud with some medium sand at the bottom. Weak lamination, faint bioturbation.

Iron crust, hard and with ochre colour. Slump structures.

ron crust around clasts, roots and in clusters. Fining upwards successions with fine pebbles to coarse sand at the bottom and fining to

Fig. 4. Sediment log from the Hollerup section with explaining text. The different sediment types and macrofossil signatures are shown in the legend in Fig. 7. 

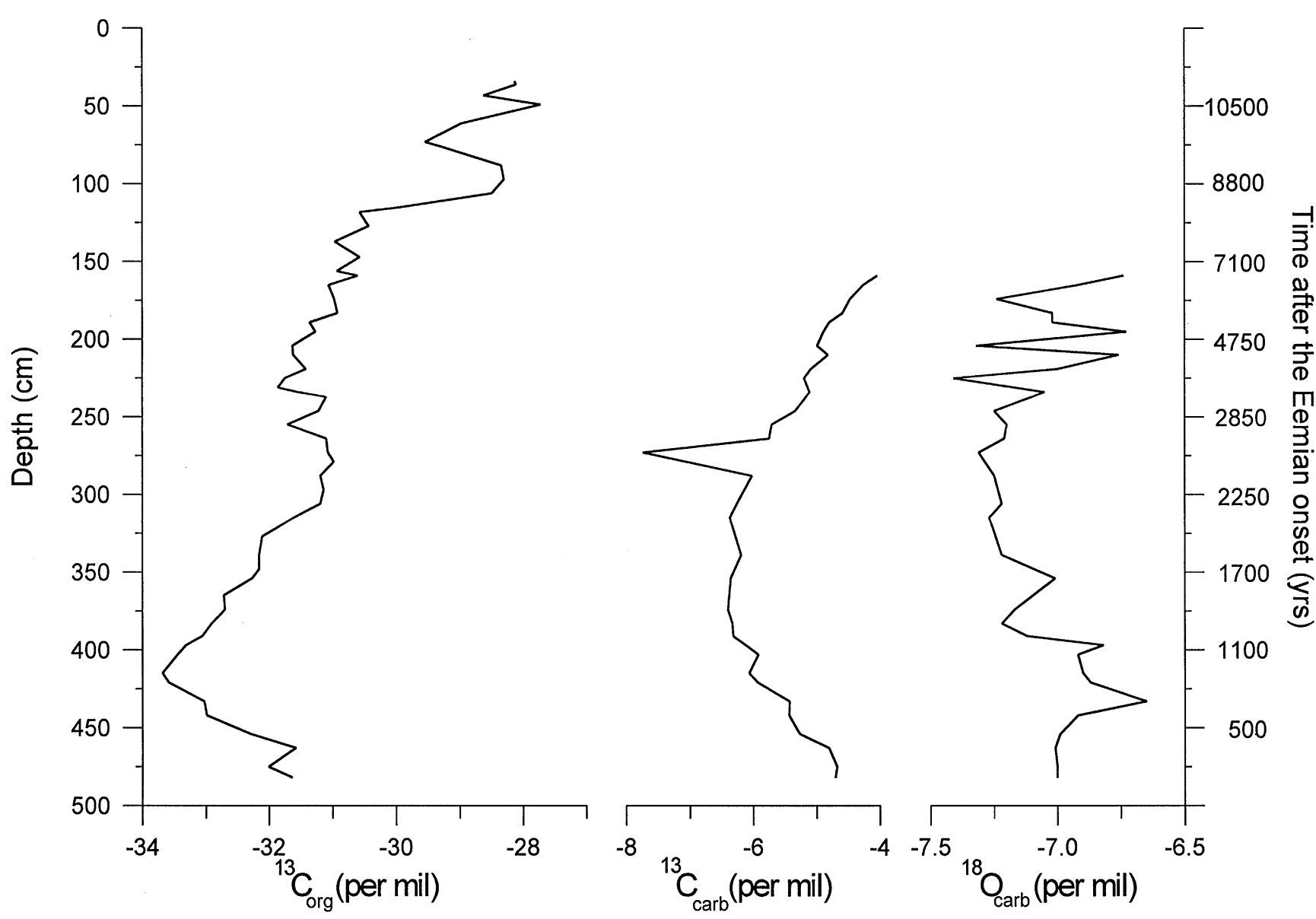

Fig. 5. Stable isotope ratios $\left(\%\right.$ in relation to the PDB standard) for $\delta^{13} \mathrm{C}$ in bulk organic carbon and carbonates and for $\delta^{18} \mathrm{O}$ in bulk carbonates, related to depth and time (see text and Table 1).

deposition by a mass flow in an unstable water-saturated environment either through solifluction or caused by a rapid lowering of the water level in a lake basin. The roots and the ironcrust impregnation indicate later subaerial exposure and weathering.

\subsubsection{Unit 2: calcareous mud facies association $(487-267 \mathrm{~cm})$}

This facies association can be subdivided into two sub-facies, a weakly laminated calcareous mud and a massive bioturbated lake marl. In our profile as well as in the older profiles the maximum thickness of this facies is about $4 \mathrm{~m}$, and it is the lower-most lake facies throughout the basin. A sharp irregular transition marks the shift from clastic meltwater sediments to lake marl and gyttja deposits.

Lake carbonates with indistinct lamination facies: This facies occurs between 487 and $360 \mathrm{~cm}$ and it consists of a very light grey colored, weakly laminated, lime mud with abundant Characean algae stems. In the lowermost $20 \mathrm{~cm}$ of this unit medium sand is mixed with the lake marl. The sand fines upwards into silt and in some levels minor amounts of clay are present. Bioturbation is weak in the lower part, but increases towards the top and so does the amount of very well-preserved complete oak leaves as well as fruits and stems. Most of the organic material is carbonized. Staining from humic matter also increases towards the top. Dark bands occur throughout the succession and the preservation of organic matter seems to be better in these than in the rest of the lime mud. Apart from the lowermost part of the succession, the carbonate values are stable at around $90 \%$, with only minor amounts of organic and mineral matter. $\delta^{13} \mathrm{C}_{\mathrm{org}}$ values decrease from -32 to $-34 \%$ in the lower part and rise again in the upper part of the facies association. The $\delta^{18} \mathrm{O}_{\text {carb }}$ values are around $-7 \%$, which is close to the average value of $-9 \%$ of present day precipitation in Denmark, but a small maximum occurs between 450 and $400 \mathrm{~cm}$, followed by more negative values at $380 \mathrm{~cm}$ and returning to values around $-7 \%$ at $360 \mathrm{~cm}$. The $\delta^{13} \mathrm{C}_{\text {carb }}$ values decrease with a few excursions from -4.5 to $-6.5 \%$.

The silty grain size and weak lamination, without current or wave generated structures, indicate lacustrine deposition from suspension under a wave base. The abundance of Characeans stems indicates a lush bottom 

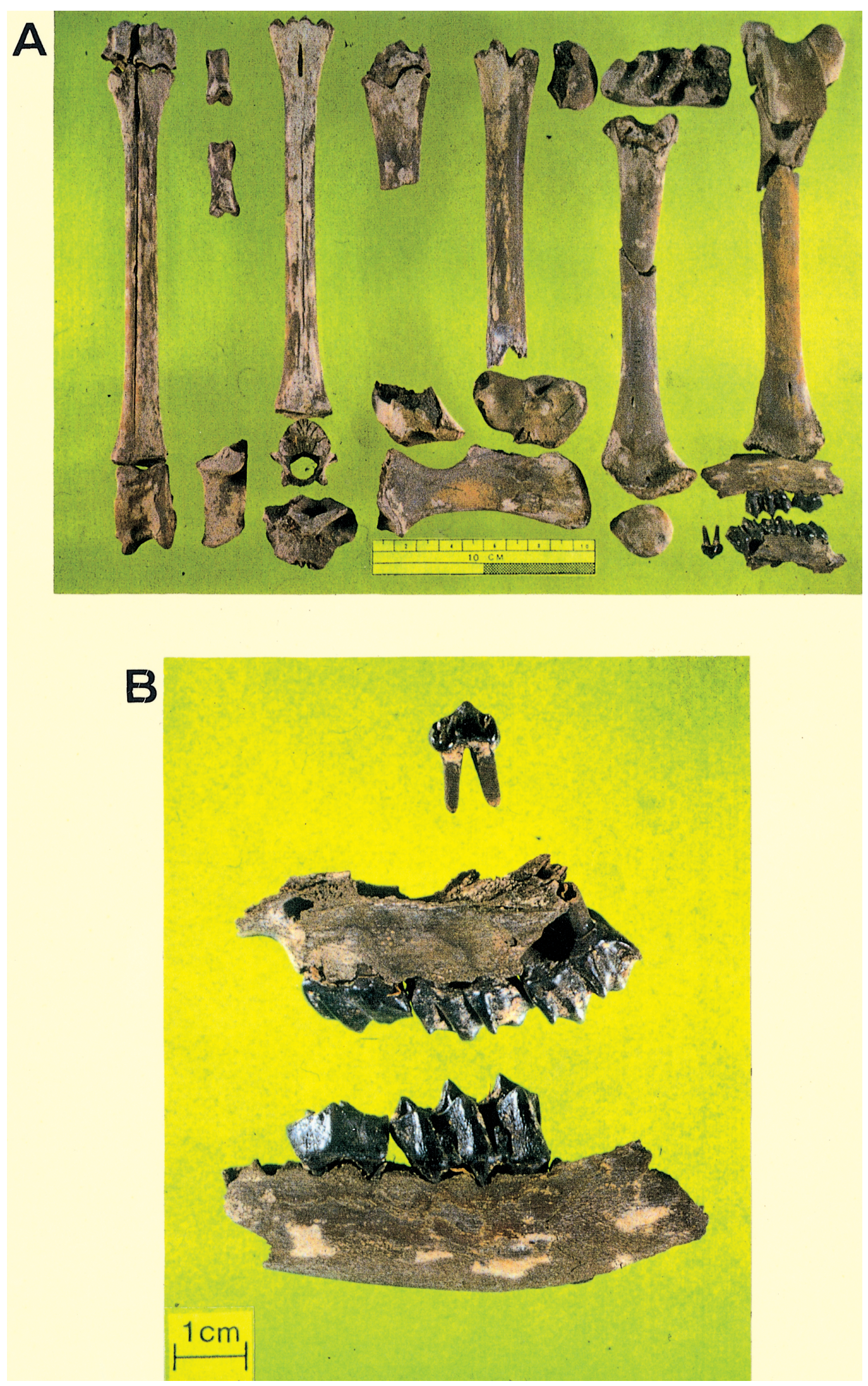

Fig. 6. (A) Bones from a ca. 3 month old calf of fallow deer (Dama dama), found at the transition between the lake carbonates and the detritus gyttjas at c. $250 \mathrm{~cm}$ depth (Figs. 3 and 4). The porous juvenile bones are very well preserved. (B) Bones and teeth from upper and lower jaw. 
vegetation of this calcareous algae in a clear, hard water lake, which allowed growth of this light demanding algae from wave base down to at least a couple or more meters. Apart from the abundance of Characean algae, the low organic content and the presence of terrestrial plant fossils indicate a low aquatic productivity. The $\delta^{18} \mathrm{O}_{\text {carb }}$ values are within the normal range for lake carbonates in dimictic temperate hard water lakes (Kelts and Hsü, 1978; Kelts and Talbot, 1990). The minor excursions may indicate the changing influence of run-off water and residence time ratios. The gradually more negative $\delta^{13} \mathrm{C}_{\text {carb }}$ values may point to a change from the dominance of surface/shallow waters and high evaporation towards a deeper lake more influenced by ground water inflow and $\mathrm{CO}_{2}$ released by decomposition of organic matter near the bottom (Talbot and Kelts, 1991). Characean algae and abiotic precipitation from the surface waters are assumed to be the dominant source of carbonate. The very negative $\delta^{13} \mathrm{C}_{\mathrm{org}}$ values may indicate an increase in local algae production with negative values, in casu Characean algae, or an increase in anoxic microbial decomposition and methanogeneses. During the latter process the methane is oxidized and produces $\mathrm{CO}_{2}$ strongly depleted in ${ }^{13} \mathrm{C}$ (Kelts and Talbot, 1990). The interpretation of the stable isotope parameters combined with the sedimentological evidence indicate changing lake level, superimposed on a generally rising trend. This interpretation is also in good accordance with the diatom data (see below).

Massive silty lake marl facies. This facies comprises a light grey, fine grained massive uniform lake marl between 360 and $267 \mathrm{~cm}$, with some distinctly dark spotted levels. The amount of organic matter increases towards the top, which is marked by an increasing brown colouring of the lake marl. Faint traces of bioturbation, visible as white burrows $10-15 \mathrm{~mm}$ in width and up to $20 \mathrm{~mm}$ long in the dark grey intercalations, can be identified. Their visible presence around the greyish to blackish parts of the sediment may indicate that, in fact, the whole sediment has been severly bioturbated. Charred plant remains and operculae from Bithynia sp. occur through the entire facies. Carbonate values are high $(80-90 \%)$, but decrease slowly upwards, while the amount of organic matter gradually rises. It is noteworthy that the magnetic susceptibility and SIRM signals exhibit a number of large excursions centred around the dark spotted levels between 350 and $280 \mathrm{~cm}$. These levels contain more fine grained mineral matter (a doubling of the fraction $<63 \mu \mathrm{m}$ ), mainly consisting of dark minerals possibly dominated by ultra-fine magnetite grains (see below). The $\delta^{13} \mathrm{C}_{\text {org }}$ rises gradually to less negative values and $\delta^{13} \mathrm{C}_{\text {carb }}$ exhibits stable, but slowly rising, values around $-6 \%$, apart from a short lasting minima at $275 \mathrm{~cm}$. The $\delta^{18} \mathrm{O}_{\text {carb }}$ curve is stable around $-7.3 \%$.

The uniform silty grain size, the lack of current generated sediment structures and the bioturbated nature of the sediment suggests deposition in a relatively well oxygenated and deep lake basin below the wave base. Although Characean algae are present, the sediments were mainly chemically precipitated from the surface waters during heating of the epilimion. The increasing organic matter may, however, indicate an increasing bioinduced origin of the carbonates which is supported by a slight increase in $\delta^{13} \mathrm{C}_{\mathrm{carb}}$. The dark spotted levels suggest short-lasting transgressive events, which will be discussed below.

\subsubsection{Unit 3: fine calcareous detritus gyttja facies association $(267-120 \mathrm{~cm})$}

This facies association occurs with a $10 \mathrm{~cm}$ transition from 270 to $260 \mathrm{~cm}$. It appears as an alternating dark and light-brown organic-rich gyttja with diffuse lamination. Based on colour, lamination, clastic sediment input and structures it is possible to separate four different facies: dark-grey calcareous gyttja, homogenous light-greyish brown fine-detritus gyttja, dark brown silty fine detritus gyttja with diatoms, and brown blackish diatom-rich gyttja.

This facies association represents a period in the lake's history with increasing organic production and decreasing carbonate precipitation. Overall, the data suggests falling but fluctuating lake levels beginning with a major fall, some minor rises and falls, and finally resulting in subaerial exposure of the near-shore environment at $120 \mathrm{~cm}$ (Fig. 3B).

Dark grey, calcareous gyttja facies. The transition to the underlying carbonate-rich gyttja is gradual but occurs within a short interval. The facies occurs from 267 to $241 \mathrm{~cm}$ with faint laminae in the lower half. It contains numerous black plant fragments, some of which are in situ vertical stems. The lower part of the succession is highly bioturbated. At $250 \mathrm{~cm}$ a nearly complete skeleton of a 2-4 month old calf of fallow dear (Dama dama L.) was found (Fig. 6A and B) and later retrieved. No working traces sensu Noe-Nygaard $(1990,1995)$ were found. The carbonate content decreases rapidly from 85 to $60 \%$, while organic matter increases from 10 to $30 \%$ and minerogenic matter increases slowly.

The increase of coarser clastic and organic input around $260-270 \mathrm{~cm}$ indicate enhanced out-wash of terrestrial material. This is interpreted as indicating a short lasting fall in lake level, which is supported by a very distinct decline in planktonic diatoms (see below). The deflection of $\delta^{13} \mathrm{C}_{\mathrm{org}}$ values towards more negative values $(-32 \%$ ) at $255 \mathrm{~cm}$ may indicate a higher autochtonous organic input, probably by algae, or an increased mixing of the DIC with depleted $\mathrm{CO}_{2}$ originating from the organic decomposition at the lake bottom. The following fining upwards trend indicates increased sedimentation from suspension in a deeper water body, probably caused by increased precipitation. The latter assumption is supported by a distinct susceptibility/SIRM peak and a rapid increase in planktonic diatoms (see below). 
Distinct levels of bioturbation indicate that the lake periodically was well-oxygenated. The marked change from the underlying carbonate-dominated facies to a more organic dominated sediment implies increased eutrophication. This change represents a clear and very important shift in the lake system, indicating higher local productivity. The less negative values of $\delta^{13} \mathrm{C}_{\text {carb }}$ support the assumption of higher organic production in the lake leaving the DIC in the epilimion more positive and thus also the bioinduced precipitated carbonate. The generally less negative $\delta^{18} \mathrm{O}_{\text {carb }}$ values may indicate stronger influence of surface water evaporation and/or a shallowing water level and/or longer residence time. This $\delta^{18} \mathrm{O}$ trend may thus be interpreted in different ways, but in combination with sediment development and the diatom data (see below) a generally shallower lake level than in Unit 2 is inferred.

Homogenous light-greyish brown carbonate-rich, finedetritus gyttja facies. This facies occurs from 241 to $216 \mathrm{~cm}$ and the lower boundary is transitional. The sediment is fairly rich in macrofossils such as terrestrial leaves, sticks and a large amount of fishbones, some of which have been determined to the species Esox lucius L. and Perca fluviatilis L. The carbonate content falls continuously (from 60 to $35 \%$ ), organic matter is stable around $40 \%$, while mineral matter, including diatom opal, rise to $25 \%$. The $\delta^{18} \mathrm{O}_{\text {carb }}$ and $\delta^{13} \mathrm{C}_{\text {org }}$ values fluctuate considerably, but the $\delta^{13} \mathrm{C}_{\text {carb }}$ curve displays steady rising values.

This facies is a continuation of the transition between the lake marl, gyttja and diatomite facies. The sediment implies fairly high lake levels, but fluctuations are supported by the changing stable isotope, geomagnetic and benthic diatom values. The rising organic matter and $\delta^{13} \mathrm{C}_{\text {carb }}$ values, the latter resulting from an enrichment of ${ }^{13} \mathrm{C}$ of the DIC in epilimion due to increased organic production selectively removing ${ }^{12} \mathrm{C}$, show a steadily increasing lake productivity.

Dark-brown, silty, diatom- and carbonate-rich, fine-detritus gyttja facies. This facies occurs from 216 to $161 \mathrm{~cm}$ and darkens upwards with black spots. The lower parts contain some sand and are faintly laminated. Lightbrown laminae are $2-3 \mathrm{~cm}$ thick, dark laminae are $4-5 \mathrm{~mm}$. The boundary to the underlying facies is subtle and gradual. The carbonate content continues to fall, but a short-lasting rise occurs again between 190 and $165 \mathrm{~cm}$ before it drops to very low values. This carbonate rise is matched by falling organic and mineral matter. Both the $\delta^{13} \mathrm{C}_{\text {org }}$ and $\delta^{13} \mathrm{C}_{\mathrm{carb}}$ values rise, with some minor fluctuations, to -31 and $-4 \%$, respectively, while $\delta^{18} \mathrm{O}_{\text {carb }}$ displays a highly fluctuating curve.

The fining upwards trend and black anoxic spots at the top indicate an overall increase in water depth, supported by a general increase in planktonic diatoms between 215 and $180 \mathrm{~cm}$ with a minor fluctuation at $190 \mathrm{~cm}$. The varying $\delta^{18} \mathrm{O}_{\text {carb }}$ values possibly reflect changes in the balance between precipitation and evaporation. The sudden increase in carbonates at $170-180 \mathrm{~cm}$ may be due to either an increased input of detritial carbonates from the surrounding environment by, e.g. increased precipitation/run-off or may be explained by decreased disintegration of already deposited carbonates by organic decomposition. The latter explanation is supported by the contemporaneous fall in organic matter.

Light-grey brown, diatom-rich, fine-detritus gyttja facies. This 3-5 cm thick facies occurs from 161 to $158 \mathrm{~cm}$. With an almost equal amount of carbonates, organic and mineral matter it constitutes the transition between the carbonate-dominated lake deposits and the diatomite-gyttja deposits. The lower boundary is very sharp.

Brown-blackish, diatom-rich, fine algae detritus gyttja facies. This facies occurs from 158 to $120 \mathrm{~cm}$. The transition to the $3 \mathrm{~cm}$ thick underlying unit is undulating and sharp. Grain-size is clay coarsening upwards. Parts of the sediment occur as green-coloured lumps with black rims. These lump-like structures are more frequent upwards, where they have the appearance of rip-up clasts and occur together with single sand grains. The topmost lumps are surrounded by the same type of sediment as the overlying sediment unit. Between 158 and $153 \mathrm{~cm}$ the sediment seems slightly darker and appears more humified than higher up in the section. Organic matter reaches a maximum of $60 \%$ at $130 \mathrm{~cm}$. The almost total lack of carbonates above $150 \mathrm{~cm}$ made analyses of $\delta^{18} \mathrm{O}_{\text {carb }}$ and $\delta^{13} \mathrm{C}_{\text {carb }}$ impossible. The $\delta^{13} \mathrm{C}_{\text {org }}$ values slowly increase to around $-30.5 \%$ towards the top of the facies.

The general change in sediment parameters indicates a dramatic shift in the hydrological conditions of the lake. The increase in organic material and decrease in mineral matter implies that the organic material originated from shallow water phytoplankton other than diatoms, such as e.g. blue-green algae blooms, as indicated by the colour. The cracks and the rip up clasts in the top layer indicate subareal exposure of the gyttja and/or bottom-freezing in winter of the sediment surface. Both of these processes may result in the signs of desiccation found in the upper part of this facies, and both situations also imply extremely low lake levels compared to the previous facies. A sudden increase in sulphur connected with this facies indicates the presence of sulphate reducing bacteria characteristic of anoxic conditions. The latter is typical for shallow productive lakes with long periods of ice cover. This shallow water environment is further supported by the increase of benthic diatoms from 60 to $97 \%$ between 158 and $120 \mathrm{~cm}$ (see below).

\subsubsection{Unit 4: diatom-rich gyttja facies association $(120-35 \mathrm{~cm})$}

This facies association is characterized by a generally high content of biogenic silica, opal, and organic matter. 
It also includes a transitional unit into the overlying clastic facies association (Unit 5).

Light-brown diatomite facies. Its grain size is clay and it occurs between 120 and $81 \mathrm{~cm}$ with a sharp and very irregular lower boundary. The lowermost $5 \mathrm{~cm}$ is slightly darker and the sediment is lightening upwards with distinct light spots at the top, where also faint lamination $(3 \mathrm{~cm}$ thick laminae) and faint bioturbation occur. Organic matter content drops from 60 to $20 \%$ whereas the mineral matter increases to $75-80 \%$. The $\delta^{13} \mathrm{C}_{\text {org }}$ record displays a clear maximum with values around $-28 \%$.

The sudden increase in mineral matter, probably diatom opal, together with fine grained organic matter, give this sediment its special character. The complete dominance of (benthic) diatoms suggests a shallow lake with some influence from near-shore and terrestrial organic matter, as indicated by the less negative $\delta^{13} \mathrm{C}_{\text {org }}$ values. Although lake level was fairly low, it was significantly higher than in the preceding facies.

Brown, fine diatomite gyttja facies. This fairly compact and fine-grained sediment occurs at $81-51 \mathrm{~cm}$ with a sharp and straight lower boundary. Plant macro remains are abundant in the lower part. Up to $76 \mathrm{~cm}$ the diatomite is faintly laminated on a mm scale, infrequently bioturbated with thin white spotted layers at the top. At $76-51 \mathrm{~cm}$ it becomes faintly laminated with up to $3 \mathrm{~cm}$ thick light laminae separated by $4-5 \mathrm{~mm}$ darker layers. Around $65 \mathrm{~cm}$ the laminations and traces of bioturbation disappear and the unit becomes more massive. The organic content is about $20 \%$ and the rest consists almost totally of mineral matter, mainly opal.

No clear signs of lake level change can be seen from the sediment, but the negative $\delta^{13} \mathrm{C}_{\text {org }}$ excursion and increasing planktonic diatoms at $75 \mathrm{~cm}$ (see below) may indicate a lake level rise at the transition between the two diatomite facies.

Dark-brown, homogenous diatom-rich, clayey detritus gyttja with small sand lenses facies. It occurs between 51 and $40 \mathrm{~cm}$ and the lower boundary is sharp and undulating. The sand lenses are c. $2 \mathrm{~cm}$ long and $1 \mathrm{~cm}$ thick. The amount of organic matter gradually decreases to $10 \%$ and carbonates rise to a few percent. The $\delta^{13} \mathrm{C}_{\text {org }}$ values oscillate ranging between 28 and $29 \%$.

The sand, probably transported by bottom currents into the lake, indicates out-wash of clastic material from land suggesting less dense vegetation/increased soil erosion. The latter is supported by increased occurrence of redeposited pollen grains (Andersen, 1965) and carbonates. The drastically decreased organic content implies decreased lake productivity, and together with the complete dominance of benthic diatoms, all these facts point to a fairly shallow lake in a generally cooler climate.

Light-brown silty clay-gyttja facies. This facies, with a few 1-2 cm long sand lenses, occurs between 40 and $35 \mathrm{~cm}$. Its lower boundary is gradual. The clay seems to have been pushed or loaded into a softer gyttja bed. This constitutes the end of a transition between the pure diatom gyttja and the overlying, mainly clastic dominated, facies. The organic matter gradually decreases to $5 \%$ and carbonate values are low. The $\delta^{13} \mathrm{C}_{\text {org }}$ values are around $-28 \%$.

The fine grain size indicates deposition in calm and not too shallow water. The mixed clay and gyttja and the fast, abrupt change in many other parameters may indicate that the sedimentation of clay into non-consolidated gyttja was the result of a hydrologic event, but on the other hand clastic material was becoming increasingly available in the near-by environment probably as a result of the cooling and deterioration of the vegetation cover.

\subsubsection{Unit 5: clastic dominated facies association $35 \mathrm{~cm}$ and upwards)}

This facies, which ends the Hollerup section, is dominated by sandy, silty and clayey deposits with only minor amount of organic material. The upper part of this unit was not analysed for diatoms or geochemical parameters.

Grey silty clay with contorted sand bands facies. This clay, containing $1 \mathrm{~cm}$ thick contorted sand bands, occurs from 35 to $15 \mathrm{~cm}$. The lower boundary is gradual. Silt coarsens upwards into medium sand. Scattered occurrences of organic macro remains, most likely terrestrially derived, are found.

The contorted sandbeds indicate rapid sedimentation and deformation of unconsolidated sediments. The coarsening upwards trend and the input of terrestrial plant material indicate lowering of lake level or increased run off from surrounding land areas.

Laminated sand and clay alternating with pure sand beds facies. This facies is found from $15 \mathrm{~cm}$ to $-10 \mathrm{~cm}$. The lower boundary is sharp. In the lower part alternating sand and clay occurs. Clay dominates at the bottom. In the middle part $6 \mathrm{~cm}$ of pure structureless sand occurs, followed by laminated clay and sand on the top. Fairly sharp boundaries delimit the coarse sand bed from the laminated clay and sand beds. This facies is overlain by pure sand.

It is not possible from the exposure to determine the process of deposition, but the uniform coarse grain-size changing between laminated clay and sand beds indicates deposition in pulses, with changing and at times high energy fluxes. The lack of organic matter indicates low production in the lake and sparse vegetation cover of the surroundings.

\subsection{Concluding remarks on the relationship between sedimentology, stable isotope data and lake levels}

Both the underlying and the upper clastic deposits show sediment structures indicating deposition by running water, and it is likely that the Hollerup basin, at least in periods, was an open basin. This assumption is 
supported by the poor co-variance of the $\delta^{18} \mathrm{O}_{\text {carb }}$ and $\delta^{13} \mathrm{C}_{\text {carb }}$ values and the very little variation in $\delta^{18} \mathrm{O}_{\text {carb }}$ $(-7.5$ to $-6.5 \%$ o). The latter, which suggests relatively constant lake water composition combined with the larger variation in $\delta^{13} \mathrm{C}_{\text {carb }}(-4$ to $-8 \%$ ), is characteristic for open basins (Talbot, 1990). Furthermore, the isotopic composition of the Hollerup carbonates is very similar to those of the open Greifensee basin in Switzerland (McKenzie, 1985; Talbot, 1990). The small variations in $\delta^{18} \mathrm{O}_{\text {carb }}$ may reflect minor oscillations in temperature and inflow-evaporation balance between periods of carbonate precipitation. In fact, the oxygen isotopic composition of primary carbonates from hydrologically open short-residence lakes may, with caution, be used as a guide to the composition of the regional precipitation (Talbot, 1990).

The complete disappearance of carbonates at $150 \mathrm{~cm}$ is noteworthy. It occurs during a maximum in organic matter $(40-60 \%)$ and it is likely that high productivity, leading to increased decomposition of organic debris resulted in increased $\mathrm{CO}_{2}$ release from the bottom. This increased $\mathrm{CO}_{2}$ pressure may have dissolved already deposited carbonates and increased the $\delta^{13} \mathrm{C}_{\text {carb }}$ of the DIC.

Most lakes are sensitive to even small changes in the hydrological balance and their sediments often carry evidence of variations in lake level through the history of the basin. To recognise the different sequences, key surfaces have to be identified. These are defined as either regional erosional surfaces or regionally recognizable depositional interfaces that indicate major stratigraphic breaks during sedimentation (Weimar and Krystinik 1991). The definitions were originally based on nearshore marine well logs but the concept was applied by Surlyk et al. (1993) to large, and by Noe-Nygaard (1995), to smaller lake systems to identify important key surfaces and facilitate interpretations of lake level changes. In Hollerup we have found evidence of three marked low stand systems (LST in Fig. 7) as well as three high stand systems (HST in Fig. 7) with minor oscillations, and facies analysis is one efficient way to trace these lake level variations.

As the sequence stratigraphic terminology originates from studies of marine continental margin deposits it is understandable that not all aspects can be directly transferred to lake systems, especially not the relation between sediment distribution and base level changes. River water running into a lake generally has a higher density than the lake water. Sediments are thus often transported by density under-flows, a very effective mechanism for distribution of river transported material, and it may even form an under-flow fan (Talbot, 1994). During a forced lake level fall a regressive wedge of coarse material of plants as well as sediment may form in front of an earlier formed delta or just by reworking of the lake beach. This sediment body has a reasonable preservation potential due to low wave activity and macrophyte protection. Desiccation and soil formation may take place further land-wards, but may be difficult to detect.

We have three examples of low stands at Hollerup, indicated by a soil horizon, desiccation cracks of alga gyttja and more coarse grained sediments intercalated in gyttja (Fig. 7). A base level rise in marine environments normally causes basin-ward directed sediment starvation. Sediment starvation in lakes often occurs in more near-shore areas by sediment by-pass. Delta surfaces and lake rims are often densely vegetated and only little reworking may take place when flooded. The basin-ward deposits will then be dominated by chemical and biogenic sediments often precipitated in large quantities (Talbot, 1994; Noe-Nygaard, 1995). In Hollerup we have three levels of mainly chemical or biogenic sedimentation indicating rising base level, the early carbonate precipitation, the fine detritus algae-rich gyttja and the fine grained diatom gyttja (Fig. 7).

The overall trend at Hollerup is a falling lake level after a rapid rise at the beginning of the section. The three major sediment units, lake marl, detritus gyttja and diatomite seem to be consistent with the three apparent rising and falling lake level cycles which can be identified. The highest water level probably occurred in the beginning of the succession. This is supported by data from the diatom analyses (see below), and parts of this lake level rise was probably a result of rising base level, as implied by the stable isotopes signal on carbonate which is characteristic for authigenic carbonates in groundwater-dominated lakes. This assumption is supported by a generally low input of clastic, land derived material.

\subsection{Lithologic correlations and an absolute time scale}

We have analysed the distribution of the three dominant components of the sediments: carbonates, organic matter and mineral matter (incl. diatom silica), as well as the sulphur content. Such analyses were also made by Andersen (1965). He also measured the content of diatom silica (opal). However, the resolution of the analyses differs greatly. While Andersen analysed 18 levels in $846 \mathrm{~cm}$, we have carried out 161 analyses in $477 \mathrm{~cm}$. In spite of Andersen's (1965) low resolution, his curves follow the same general trends as our detailed analyses, and include the most conspicious features (Fig. 8, Table 1). In addition 23 samples from the old section were counted for diatoms. They were analysed to confirm apparent diatom patterns present in the new section, and to control our lithostratigraphic correlations between the sections. Altogether, this makes tentative correlations possible between the two profiles. It also makes it feasible to estimate the time span of the different sediment units by relating Andersen's (1965) pollen spectra to Müller's (1974) pollen analysed, partly annually laminated sediments in Bispingen, Germany. 
LEGEND

\begin{tabular}{|c|c|}
\hline & Sand \\
\hline & Silt \\
\hline & Clay \\
\hline & Diatomite \\
\hline & $\begin{array}{l}\text { Gyttja with } \\
\text { diatoms }\end{array}$ \\
\hline & $\begin{array}{l}\text { Detritus } \\
\text { gyttja }\end{array}$ \\
\hline & $\begin{array}{l}\text { Carbonate } \\
\text { rich gyttja }\end{array}$ \\
\hline & $\begin{array}{l}\text { Cobbles } \\
\text { gravel }\end{array}$ \\
\hline & Dama dama \\
\hline & Plant remains \\
\hline & Trace fossils \\
\hline & $\begin{array}{l}\text { Carbonized } \\
\text { plant stems }\end{array}$ \\
\hline & $\begin{array}{l}\text { Black anoxic } \\
\text { ultra fine grains }\end{array}$ \\
\hline & Fish remains \\
\hline
\end{tabular}

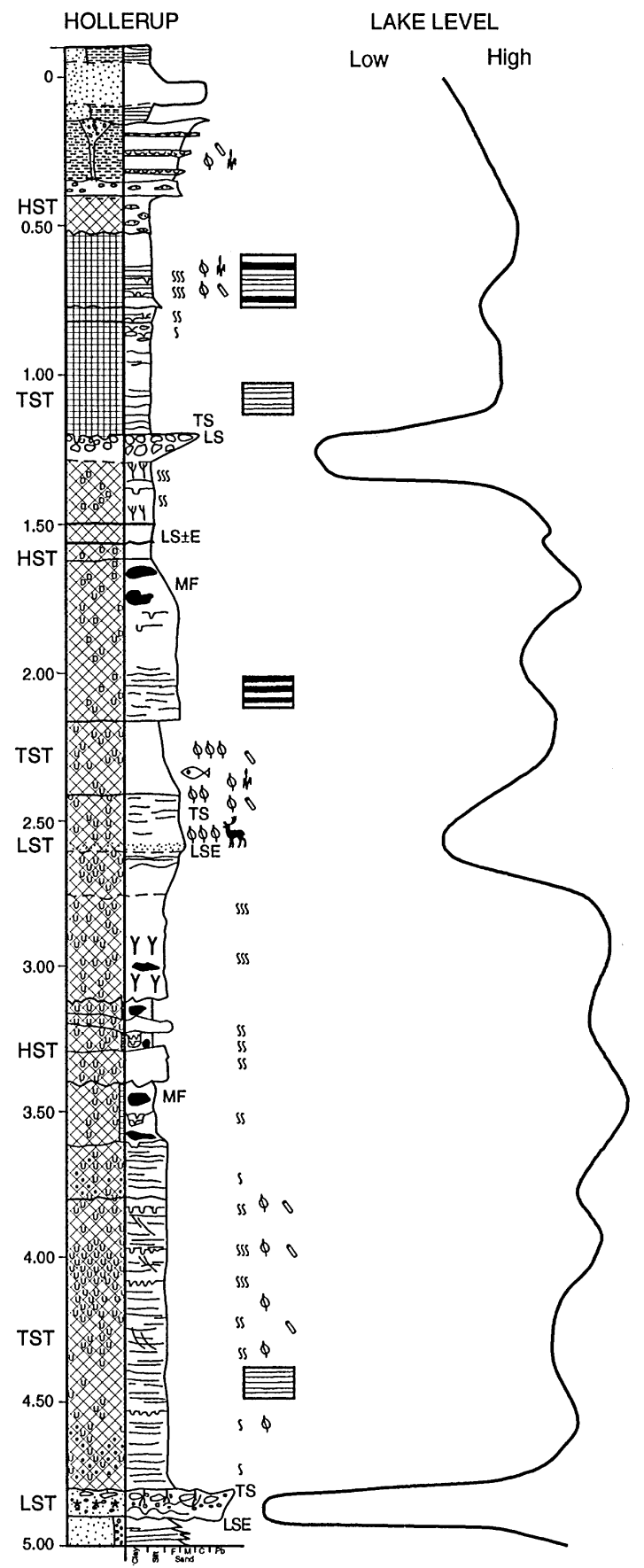

Fig. 7. Key surfaces, systems tracts and relative lake level at Hollerup, based on the sediment log, with a legend to the left. HST $=$ High Stands Systems Tract, LST $=$ Low Stands Systems Tract, TST $=$ Transgressive Systems Tract, LSE $=$ Low stand surface of erosion, TS $=$ Transgressive surface and $\mathrm{MF}=$ Maximum flooding surface.

The lowermost c. $2.5 \mathrm{~m}$ from the two Hollerup sections exhibit the same pattern in the bottom: gradually rising values of organic matter (5-20\%), very high carbonate values (70-90\%) and shifting content of mineral matter. This part of the section corresponds to Andersen's (1965) pollen zones 2-4, and according to Müller's (1974) laminae calculations these pollen zones span c. $3000 \mathrm{yr}$. This results in sedimentation rates of
$0.75-0.85 \mathrm{~mm} \mathrm{yr}^{-1}$ during the deposition of the calcareous gyttja.

The transitional sediments, between the calcareous and diatomaceous gyttjas, represent c. $85 \mathrm{~cm}$ in our profile and $165 \mathrm{~cm}$ in the old section. Carbonate values decrease from 70 to $0 \%$, organic matter increases from 20 to $45 \%$ and the mineral matter content rises from about $5-50 \%$, of which most of it is related to a rise in the opal 
content (Andersen, 1965). All these three components display some distinct oscillations in the middle of the transitional sediments. This part of the section corresponds stratigraphically to pollen zone 5 and the lower part of pollen zone 6 (Fig. 9) and is, by Müller (1974), estimated to cover c. 4000 yr. Sedimentation rates thus have decreased considerably to 0.21 and $0.41 \mathrm{~mm} \mathrm{yr}^{-1}$ in our and in the old section, respectively.

The diatomaceous gyttja is dominated by mineral matter $(50-80 \%)$ of which opal makes up $30-70 \%$. The organic content decreases from 50 to $20 \%$ and the sediment is completely void of carbonates. This part of the section, with the addition of the overlying clay gyttja, corresponds to the main part of pollen zone 6 and pollen zone 7. It is only c. $120 \mathrm{~cm}$ thick in our profile, while it was c. $300 \mathrm{~cm}$ thick in Andersen's (1965) old section (Fig. 9). Müller's (1974) estimations show that the whole time period throughout pollen zones $6-7$ is c. 4000 yr long. We thus have large differences in sedimentation rates between the two Hollerup profiles, c. $0.33 \mathrm{~mm} \mathrm{yr}^{-1}$ vs. $0.9 \mathrm{~mm} \mathrm{yr}^{-1}$.
The lower part, pollen zone 1, and the overlying zones W1-W2a, of the two Hollerup sections are relatively rich in mineral matter but not in opal. They cannot be correlated in detail. However, the sedimentation rates from the underlying units were extrapolated into the clastic Unit 5.

Our sedimentation rates are slightly lower than normal Holocene values for south Scandinavian lakes $\left(0.5-1.0 \mathrm{~mm} \mathrm{yr}^{-1}\right)$, but in contrast to Holocene sediments, the Hollerup deposits are considerably compacted. This is especially valid for the more organic-rich parts of the sediments, where the water content is very low in spite of its high organic content.

\subsection{Vertebrate fauna}

Remains of two main vertebrate groups have been found at different occasions in the Hollerup sediments: mammalians and fishes.
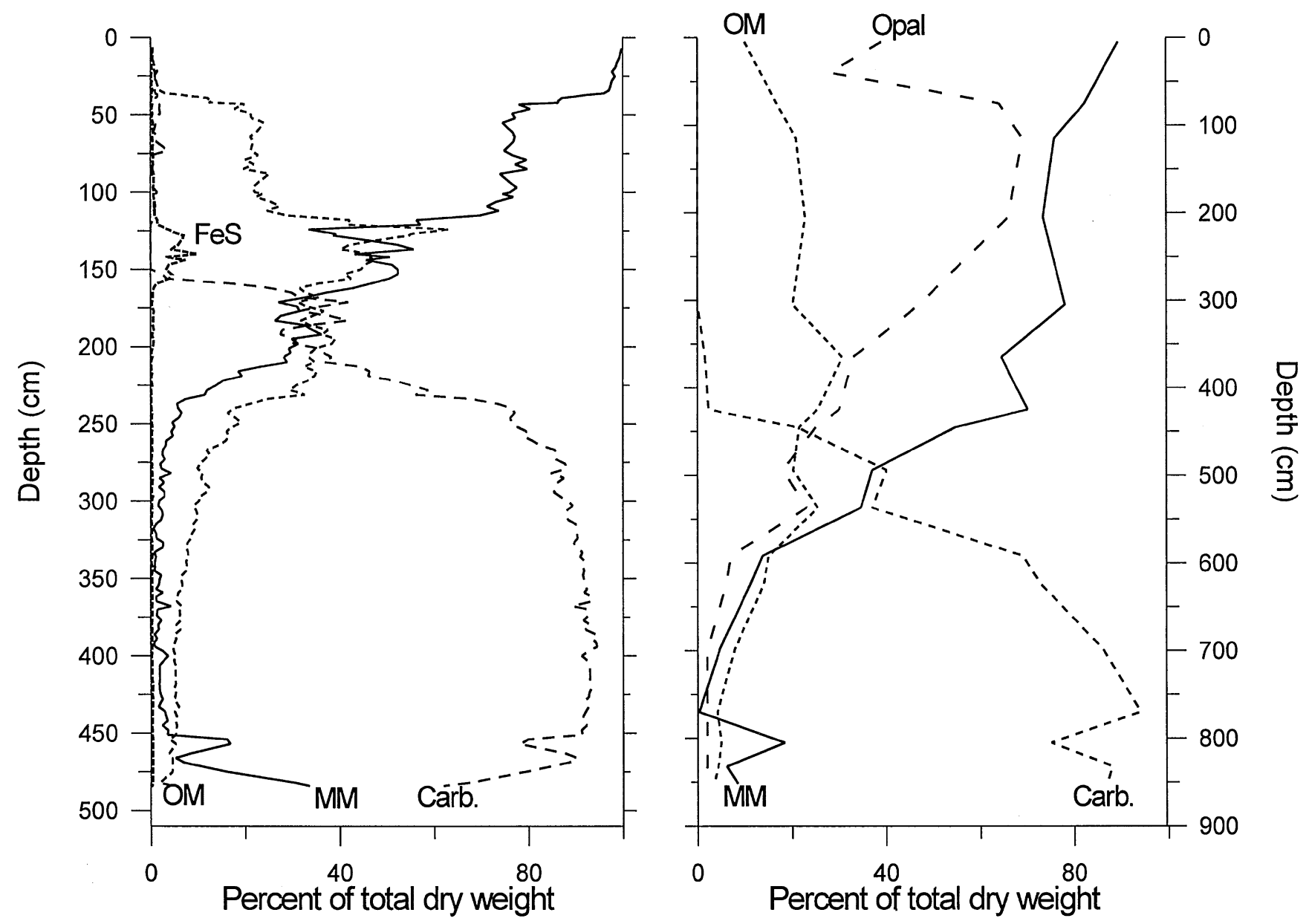

Fig. 8. Curves for the main geochemical constituents of the Hollerup sediments ( $\%$ of dry weight) are shown as two diagrams (OM $=$ organic matter, $\mathrm{MM}=$ mineral matter, Carb. = carbonates). The results from the recently studied section are shown to the left and the data from Andersen's (1965) pollen analysed section is displayed to the right. We have transformed the sulphur content into assumed FeS. Andersen (1965) also measured the opal (diatom silica), which is part of the mineral matter in both diagrams. Also note the different depth scales. 
Table 1

Correlations between the old Hollerup profile (Andersen, 1965) and the new studied profile. The main correlation depths are underlined. Estimated time span is calculated by correlations to Müller (1975) and note that sedimentation rates for the youngest sediments are based on extrapolations from pollen zones 6 and 7

\begin{tabular}{|c|c|c|c|c|}
\hline $\begin{array}{l}\text { Sediment depth }(\mathrm{cm}) \text { in } \\
\text { the old profile }\end{array}$ & $\begin{array}{l}\text { Correlated depth }(\mathrm{cm}) \\
\text { in the new profile }\end{array}$ & Pollen zone boundary & Dominating pollen types & $\begin{array}{l}\text { Time span between some } \\
\text { defined depths } \\
\text { (in par antheses) }\end{array}$ \\
\hline
\end{tabular}

\begin{tabular}{|c|c|c|c|c|}
\hline & & & $\begin{array}{l}\text { Poaceae-Cyperaceae } \\
\text {-Juniperus-Rumex } \\
\text {-Betula-Pinus }\end{array}$ & \\
\hline \multirow[t]{2}{*}{25} & $\sim 7$ & $\mathrm{~W} 1 / \mathrm{W} 2$ & & $(7 \mathrm{~cm})$ \\
\hline & & & $\begin{array}{l}\text { Poaceae-Juniperus } \\
\text {-Cyperaceae-Calluna- } \\
\text { Pinus-Rumex-Alnus }\end{array}$ & $900 \mathrm{yr}$ \\
\hline 85 & 35 & $\mathrm{~W} 1 / 7$ & & $(35 \mathrm{~cm})$ \\
\hline 115 & $\underline{50}$ & & $\begin{array}{l}\text { Pinus-Betula-Alnus- } \\
\text { Calluna-Picea- } \\
\text { Poaceae-Cyperaceae }\end{array}$ & \\
\hline 150 & 60 & $7 / 6$ & & $4000 \mathrm{yr}$ \\
\hline 310 & 90 & & & \\
\hline$\overline{370}$ & $1 \overline{25}$ & & $\begin{array}{l}\text { Pinus-Picea-Alnus-Betula- } \\
\text { Calluna-Poaceae- } \\
\text { Cyperaceae }\end{array}$ & \\
\hline 425 & 153 & & & $(153 \mathrm{~cm})$ \\
\hline$\overline{495}$ & $\overline{175}$ & $6 / 5$ & & \\
\hline$\overline{540}$ & $\overline{195}$ & & $\begin{array}{l}\text { Carpinus-Picea-Alnus- } \\
\text { Pteridium-Betula }\end{array}$ & $4000 \mathrm{yr}$ \\
\hline 590 & 240 & $5 / 4$ & & $(240 \mathrm{~cm})$ \\
\hline & & & $\begin{array}{l}\text { Corylus-Alnus-Quercus- } \\
\text { Taxus-Ulmus }\end{array}$ & \\
\hline 785 & 430 & $4 / 3$ & & \\
\hline 810 & 455 & & $\begin{array}{l}\text { Quercus-Pinus-Fraxinus- } \\
\text { Juniperus-Ulmus-Rumex }\end{array}$ & $3000 \mathrm{yr}$ \\
\hline 825 & 465 & $3 / 2$ & $\begin{array}{l}\text { Pinus-Betula-Salix- } \\
\text { Poaceae-Rumex- } \\
\text { Ulmus }\end{array}$ & \\
\hline 842 & 475 & $2 / 1$ & $\begin{array}{l}\text { Betula-Salix-Poaceae- } \\
\text { Rumex }\end{array}$ & \\
\hline 851 & 484 & & & $(484 \mathrm{~cm})$ \\
\hline
\end{tabular}

Mammalia; Cervidae, Dama dama L.: Bones from a skeleton of a 2-4 month old calf of fallow deer (D. dama) were recovered (Fig. 6). They were found at a depth of 260-250 cm, just above the calcareous gyttja, in the calcareous rich fine detritus gyttja (Fig. 4). The same sediment setting is recorded for the other finds of fallow deer from the Danish Eemian lakes, i.e. just above the transition between the marl and the diatom containing gyttja. ("In the Mo over the Marl" from N. Hartz's field note-book according to Møhl-Hansen (1954)).

The calf skeleton was very well preserved and included parts of the calvarium with fragments of maxillae with $\mathrm{dp}^{4}$ and $\mathrm{m}^{1}$, two fragments of left and right mandibulae with $\mathrm{dp}_{2}, \mathrm{dp}_{3}$ and $\mathrm{dp}_{4}$, two upper halves of humerus with loose epiphyses, two lower ends of femur including part of the diaphysis and with loose epiphyses, two tibiae, one almost complete and one lower half with loose epiphyses, two complete metatarsii, sixteen fragments of vertebrae from the entire column, a few costae, a pelvis fragment, one right astragallus and one left calcaneous and a number of phalangae. Tibia, femur and humerus was broken right across the diaphyses, but there were no traces of cut marks or other human traces as defined by Noe-Nygaard (1990, 1995). The breakage was most likely caused by sediment compaction and loading. Fallow deer are well known from the European last interglacial and it occurs in Danish Eemian lake deposits together with red deer (Cervus elaphus L.). It does, however, disappear from Denmark during the last glaciation and it is thus only known as a natural member of the Danish fauna from the Eemian.

Fourteen Danish finds of fallow deer were recorded by Møhl (1954) and except for one from Fyn all others were reported from Mid-east Jylland. Four of the former finds 
of fallow deer were from the Hollerup site. In 1954, Møhl demonstrated that the bones from one of the individuals, an old female, from Hollerup were broken in a remarkably uniform way. He interpreted this breakage as a result of marrow fracturing produced by man at an interglacial Mid-Palaeolithic hunting camp inhabited by Homo neanderthalensis. The bones have been re-examined, but no other evidence of human influence in terms of cut marks, chop marks, dog gnawing or flint implements have been found.

The recovery of the calf did not add further insight to the assumption of the presence of man at Hollerup. But such a young calf is not likely to have been alone and may thus have been the calf of one of the adults earlier recorded from the site.

Fallow deer prefers open park vegetation, such as mixed deciduous forest with a lush bottom vegetation including various grasses. The animals are primarily grass eaters but they are also frequent browsers. They live in herds, but the males do not have harems like the red deer. The calves are born in June-July and stay with their mother for nearly a year, so if the calf belongs to one of the adults with marrow fractured bones the site was visited by man in September- October, when the animals are fat and preoccupied by mating. Fragments of antlers have also been recorded from Hollerup. D. dama has antlers from late September to April.

The presence of fallow deer at Hollerup, just above the calcareous gyttja, indicates that a rich, varied and open forest existed at that time. This is in accordance with our correlation with Andersen's (1965) pollen stratigraphy, which places this boundary at the transition between pollen zone 4, dominated by Corylus, Alnus, Quercus, Taxus and Ulmus pollen grains and the Carpinus pollen zone, zone 5 (Fig. 9; Table 1). This is, however, in contrast to the rather negative $\delta^{13} \mathrm{C}$ value of $-31.3 \%$ measured on bone collagen from the calf described above. Such low values may be a result of diagenetic changes of the porous calf bones; the enclosing sediments have a $\delta^{13} \mathrm{C}$ value of $-31.7 \%$ (Fig. 5). However, these low values may also be a result of continuing lactation. Results from ${ }^{13} \mathrm{C}$ analyses of modern and fossil juvenile vs. adult red deer from the same population show lower values from juveniles still lactating compared to contemporary adults (Noe-Nygaard, 1995).

Pisces; Pike (Esox lucius L.), Perch (Perca fluviatilis L.) and Bream (Abramis brama L.): Several bones from both head, shoulder and vertebrae column as well as scales were excavated at $260-250 \mathrm{~cm}$. All these species were, however, already known from the description by Jessen and Milthers (1928). The presence of these three fish species indicates a fairly deep meso- to eutrophic lake with muddy bottom, where the bream thrives close to the muddy bottom and pike finds its prey (e.g. perch and rudd) in the vegetated zone along the rim of the lake.

\subsection{Diatom stratigraphy}

Part of the lake development is reflected by the general diatom succession (Fig. 10) and seven major diatom zones were identified through DCA (Fig. 11).

Zone I $(480-453 \mathrm{~cm})$ : This zone is represented by the six lowest samples, which are dominated by a diverse benthic diatom flora composed of Amphora, Achnanthes and Fragilaria species. The mean percentage of benthic diatoms in this zone is $92 \%$ with a distinct decline in the topmost level (Fig. 12). Diatom-reconstructed NEW pH values decrease from more than 8 to c. 7 at the top of the zone (Fig. 13). A similar pattern is seen in the diatominferred total phosphorus (TP) as phosphorus initially increases then declines.

Zone II (453-367 cm): Planktonic diatoms, chrysophycean cysts and sponge spicules increase significantly in this zone. The diatom plankton reaches several maxima over $50 \%$ and is dominated by Cyclotella rossii Haakansson and C. distinguenda v. unipunctata (Hustedt) Haakansson \& Carter. Both taxa have low to moderate phosphorus optima. Diatom remains are scarce (less than 100 valves) in three samples. The zone is characterized by very large shifts between benthic and planktonic assemblages, with mean values of $62 \%$ and $38 \%$, respectively. Diatom inferred $\mathrm{pH}$ values (NEW $\mathrm{pH}$ ) usually vary between 7 and 7.5, but with two distinct peaks of 8.5 at 435 and $415 \mathrm{~cm}$, coincident with peaks in benthic diatoms. The mean $\mathrm{pH}$ for the zone is 7.3. After increasing in the beginning of the zone, TP declines.

Zone III $(367-313 \mathrm{~cm})$ : Six of the 11 samples in this zone $(365-355$ and $345-330 \mathrm{~cm})$ are poor in diatoms (38-64 valves) and those present are dominated by benthic forms. However, the planktonic taxa that are present increase in diversity. Planktonic species with moderate phosphorus optima increase (Aulacoseira italica v. subarctica, now Aulacoseira subarctica (O. Mueller) Haworth, Cyclotella bodanica Grunow, Stephanodiscus alpinus Hustedt and S. medius Haakansson), while C. rossii declines. Mean benthic and planktonic values are $76 \%$ and $24 \%$, respectively. The general trend in diatom-inferred $\mathrm{pH}$ is an increase from Zone II, with a mean value of 7.9 and with most values between 7.5 and 8.5. Several fluctuations to lower $\mathrm{pH}$ occur, which coincide with maxima in planktonic species. TP trends are also higher than in Zone II but decline in the upper samples.

Zone IVa (313-243 cm): Planktonic diatom assemblages present in Zone III persist in the beginning, but decline to c. $20 \%$ of the assemblage at the end of Zone IVa, and have a mean value of $40 \%$ (Fig. 12). Diatom taxa of increasing phosphorus optima (Aulacoseira ambigua (Grunow) Simonsen, A. granulata (Ehrenberg) Simonsen, A. granulata v. angustissima (O. Mueller) Simonsen, Cyclostephanos dubius (Fricke) Round and Stephanodiscus minutulus (Kuetzing) Krieger) first appear 


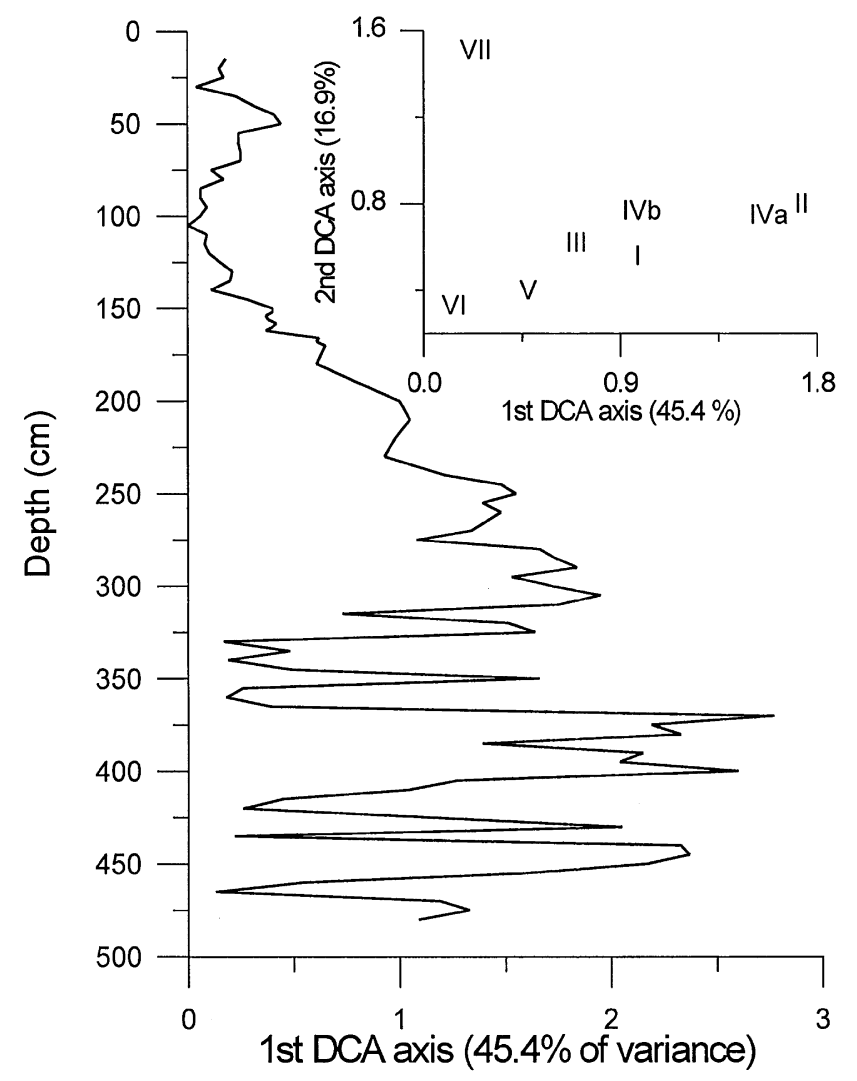

Fig. 11. Detrended correspondence analysis (DCA) on the diatom set from Hollerup, with the values of the first DCA axis related to depth. Also shown at the top are the first two DCA axes, covering $62.3 \%$ of the variance, with the mean $x$ - and $y$-values for each of the eight different diatom zones.

and benthic diatom taxa begin to increase in the middle of the zone. Chrysophycean cysts and sponge spicules show a distinct decline. Diatom-inferred $\mathrm{pH}$ increases from c. 7.2 in the lower part of the zone to c. 7.7 (a mean value of 7.5) with minor fluctuations throughout. TP has fairly low values in the beginning of the zone but exhibits an increasing trend from $290 \mathrm{~cm}$ and upwards.

Zone $I V b(243-185 \mathrm{~cm})$ : Benthic diatom assemblages become dominant (mean value of $71 \%$ ) as planktonic assemblages continue to vary (between 23 and 36\%). C. rossii increases before declining, but all other planktonic taxa from Zone III decline (Aulacoseira italica v. subarctica, C. bodanica, C. unipunctata, S. alpinus, S. medius and $S$. minutulus), while $A$. granulata, A. granulata v. angustissima, A. ambigua and C. dubius increase slightly. Diatom-inferred $\mathrm{pH}$ increases to c. 8 (a mean value of 7.9) at the top (Fig. 13) and TP values show a general increasing trend with a decline in the middle of the zone.

Zone V $(185-147 \mathrm{~cm})$ : Planktonic taxa vary between 20 and $40 \%$ (a mean value of $30 \%$ ) with highest values in the earlier part of the zone. Planktonic assemblages show a distinct change in composition. C. rossii disappears while moderate TP taxa (A. italica v. subarctica,

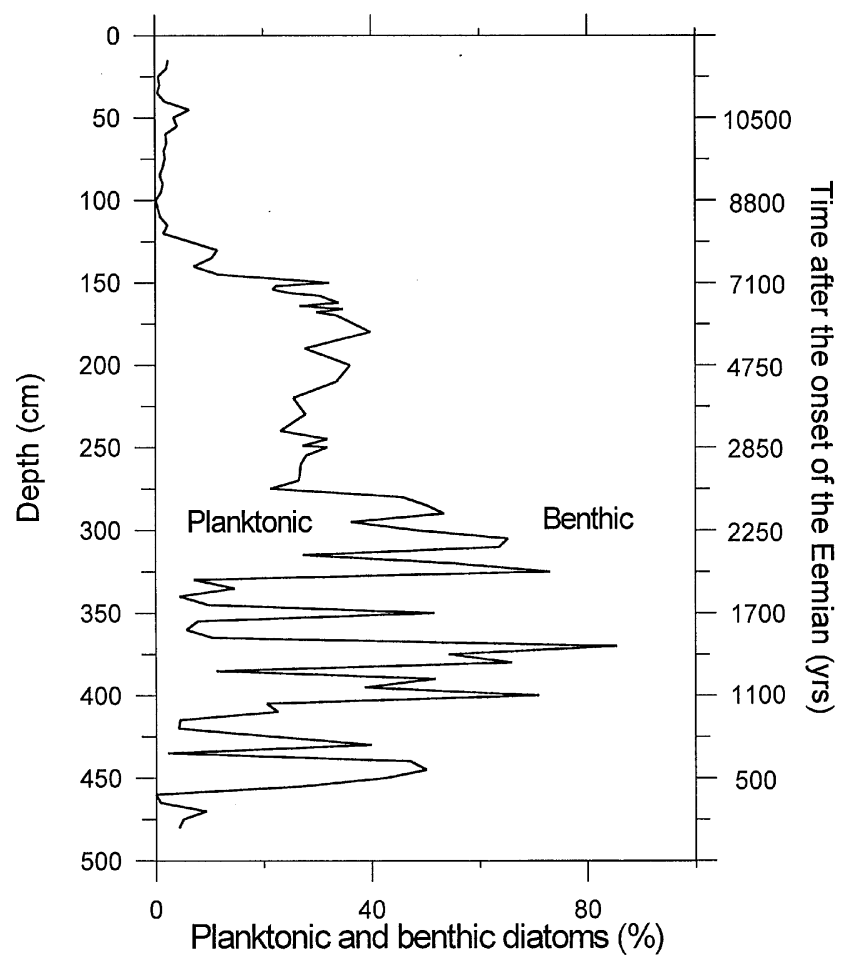

Fig. 12. Relative abundance of benthic and planktonic diatom types (Fig. 10), related to both depth and time.

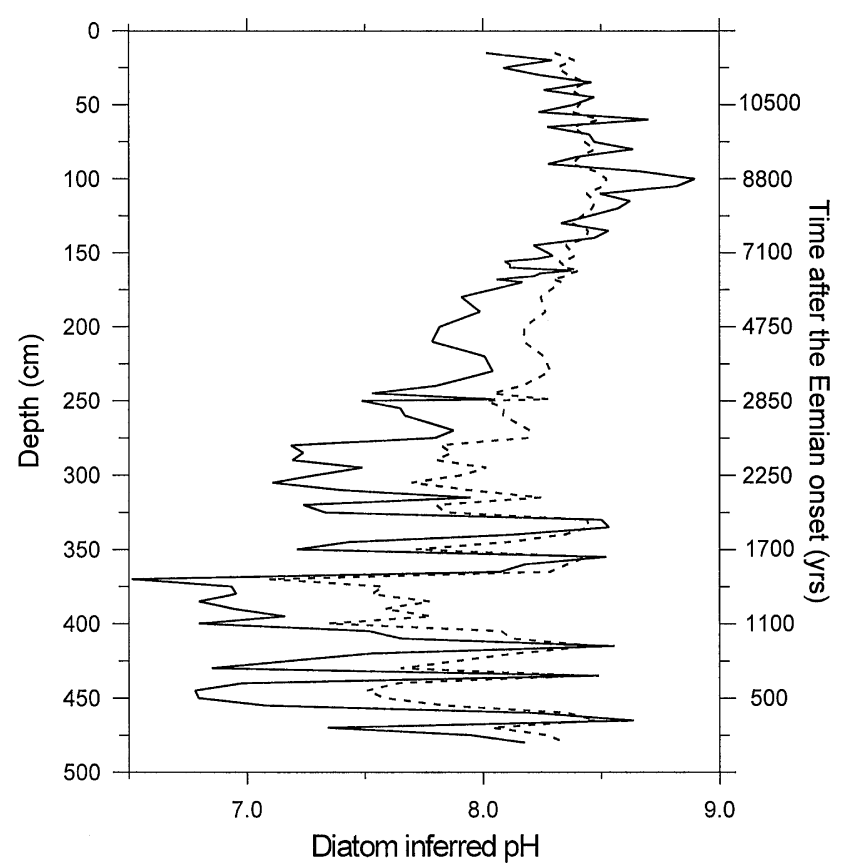

Fig. 13. Diatom inferred $\mathrm{pH}$ related to depth and time. The continuous curve is based on Håkansson's (1993) new pH formula (NEW pH) and the dashed curve is based on his multiple regression equation (MR pH). The data set is based on $\mathrm{pH}$ and surface-sediment diatom data from 24 Swedish-Finnish circum-neutral lakes. 
C. bodanica, C. unipunctata, S. alpinus, S. medius and $S$. minutulus) continue to decline. Higher TP taxa, e.g. A. granulata and $A$. granulata v. angustissima and $A$. ambigua, increase and dominate the plankton assemblage and together with e.g. Cyclotella meneghiniana these three species also suggest a shallow wind-stressed environment with isothermal mixing (S. Fritz, 1998, pers. comm.). Diatom inferred $\mathrm{pH}$ is high and fairly stable with a mean value of 8.2 and TP continues to increase.

Zone VI $(147-57 \mathrm{~cm})$ : This zone is characterized by a dramatic decline in planktonic diatom assemblages resulting in a mean value of $96.5 \%$ for benthic taxa, but the lower part of the zone, up to $120 \mathrm{~cm}$, is also characterized by the above-mentioned species typical of isothermal mixing. Diversity in the benthic taxa declines abruptly in the beginning with Fragilaria construens (Ehrenberg) Grunow comprising $40-70 \%$ of the total assemblage. Fragilaria construens v. binodis (Ehrenberg) Hustedt, Fragilaria construens v. venter (Ehrenberg) Hustedt, Fragilaria brevistriata Grunow and Fragilaris pinnata Ehrenberg begin to increase in the latter part of this zone and a minor rise in planktonic taxa occurs. Diatominferred $\mathrm{pH}$ rises to almost 9 in the middle of the zone and then shows a gradual decline to 8.5 , which is also the mean value for the zone. Diatom-inferred $\mathrm{pH}$ and TP reach their highest levels when benthic diatoms constitute more than $99 \%$ and TP begins to decline at the end of the zone.

Zone VII $(57-15 \mathrm{~cm})$ : The small increase in planktonic taxa continues but quickly declines, and the mean value of $2.5 \%$ is the lowest throughout the section (Fig. 12). Diversity of the benthic assemblage continues to increase and partly approaches the composition of assemblages present during the early zones. Diatom-inferred pH declines (Fig. 13) from c. 8.5 to 8 (a mean value of 8.3). TP is lower at the beginning of this zone, then increases.

In general, we can conclude that fairly high, but considerably varying percentages of planktonic diatoms, chrysophycean cysts and sponge spicules are present in the earliest sections (Zones I-IV). The percentage of benthic diatom taxa increases to high and fairly stable values in Zone IVa and planktonic taxa gradually decline to less than $5-10 \%$ in Zones VI and VII. If these changes are related to changes in water depth, it can be concluded that the sediment in-filling of the lake may be partly responsible for the general increase in benthic diatoms from Zone IV and upwards. However, gradual sediment in-filling cannot explain the extremely distinct, but short-lasting changes of Zones I-III, or the often abrupt changes between (and within) Zones IV-VII. Except for the few levels with very low diatom sums, it is likely that many of these events are most likely related to climatically forced lake level changes.

Diatom-inferred $\mathrm{pH}$ values are circumneutral, ranging from 7.1 to 8.5 using the multiple regression method (MR
$\mathrm{pH}$ ) and from 6.5 to 8.9 using the new $\mathrm{pH}$ formula (NEW $\mathrm{pH}$ ). In the earliest Zones (I-III), pH values fluctuate as much as $1.5-2 \mathrm{pH}$ units. Values increase in Zones IV and $\mathrm{V}$ before stabilizing around 8.5 in Zones VI and VII (MR $\mathrm{pH})$. Reconstructions based on the NEW $\mathrm{pH}$ method show a decline in $\mathrm{pH}$ in Zone VII and generally show more variation between samples than the MR $\mathrm{pH}$ method. However, since the formula for the NEW $\mathrm{pH}$ model is based on normal distributions of individual $\mathrm{pH}$ groups, it approximates a truer representation of existing conditions.

Diatom species with low-phosphorus optima are dominant in the early stages of the lake, shifting to those of higher optima. Large fluctuations in diatom-inferred TP occur in the earlier Zones (I-III) before becoming more stable. Phosphorus then increases in Zones IV and $\mathrm{V}$, reaching a peak in Zone VI before declining. Another increase occurs in Zone VII reaching a maximum similar to that of Zone VI. Since there seems to be a strong co-variance between $\mathrm{pH}, \mathrm{TP}$ and benthic diatoms, there is possibly also a strong link between lake level changes and $\mathrm{pH} / \mathrm{TP}$, in the same manner as described above.

\subsection{Mineral magnetic analyses}

According to the mineral magnetic (Fig. 14) results the section can be divided into five main magnetic units.

Unit M1 (475-360 cm): This unit has fairly stable magnetic mineral concentrations (as shown by $\chi$ and SIRM values). The low S-ratio $(-0.8)$ and the $\mathrm{SIRM} / \chi$ ratio of c. $10 \mathrm{kA} \mathrm{m}^{-1}$ indicate that coarse grained magnetite dominates the magnetic properties of this unit. It should be considered that the sediments have a high calcium carbonate concentration, which is diamagnetic and can cause the SIRM $/ \chi$ ratio to increase when the concentration of ferrimagnetic minerals is low.

Unit M2 (360-175 cm): Fluctuating $\chi$ and SIRM values in this zone indicate quite variable ferrimagnetic concentrations. Peaks in magnetic concentration are associated with peaks in the $\operatorname{SIRM} / \chi$ ratio, which indicates that fine-grained magnetic particles are responsible for the increases in $\chi$ and SIRM.

Unit M3 (175-125). This section has very low ferrimagnetic concentrations (represented by the SIRM values), although $\chi$ does not decrease so dramatically. This unit corresponds to peak values in iron sulphides and organic matter.

Unit M4 $(125-50 \mathrm{~cm})$. This unit corresponds to the diatomite, and has both low ferrimagnetic concentrations and low $\chi$.

Unit M5 $(50-7 \mathrm{~cm})$. Magnetic concentration parameters ( $\chi$ and SIRM) and the $\operatorname{SIRM} / \chi$ ratio of this unit (with a high mineral content) are similar to unit 1.

To determine the origin of the fine-grained ferrimagnetic mineral, responsible for the peaks in SIRM and $\chi$, 
samples representative of units 5 to 2 were selected for more detailed mineral magnetic analyses. According to Oldfield (1994) fine-grained detrital magnetite and bacterial magnetite (magnetosomes) can be distinguished due to their different grain size distributions. Samples of fine-grained detrital magnetite (thought to be formed through pedogenic processes) generally possess high concentrations of ultra-fine grained superparamagnetic (SPM) particles, which cannot carry magnetic remanence, but which do exhibit frequency dependent magnetic susceptibility. Samples from Hollerup clearly fall into the "detrital" envelope suggested by Oldfield (1994). The acquisition of rotational remanent magnetization (RRM) is also demonstrated by the Hollerup samples, and indicates the presence of fine-grained singledomain magnetite crystals (Snowball, 1997).

Based on these observations, the peaks in $\chi$ and SIRM in unit 2 may represent the inwash of fine-grained magnetite particles formed through pedogenesis. The covariance between the $\chi /$ SIRM peaks and planktonic diatoms, terrestrial organic matter inferred from the organic geochemistry and high lake levels interpreted from the sedimentology and stable isotopes, clearly suggest that our geomagnetic peaks represent inwash of ped- ogenic material. During high lake level stands the soils around the lake were thus transgressed and the fine particles were transported out into the lake. According to Maher (1998) these pedogenic ultra-fine magnetite grains preferably form in fine-grained, organic rich, intermittently wet/dry soils in a temperate climate. If our geomagnetic peaks are completely dominated by such soil derived particles, and we calculate them into susceptibility of pure mineral matter, these values $(25-60 \chi$ $10^{-6} \mathrm{~m}^{3} \mathrm{~kg}^{-1}$ ) correspond to a mean annual precipitation of 500-1000 mm (Maher, 1998).

\subsection{Organic geochemistry}

The main purpose of these analyses was to evaluate if the gradual change from a carbonate-dominated marl to an organic dominated gyttja, which also represents the transition to the Carpinus pollen dominated zone, could be related to changes in the allochtonous/autochtonous ratio of the organic material in the sediments. For this reason the organic material in six levels between 230 and $290 \mathrm{~cm}$ was analysed by gas chromatography for their Odd/Even Preference Index (OEP) on the aliphatic fraction and the ratio between long and short carbon-chains
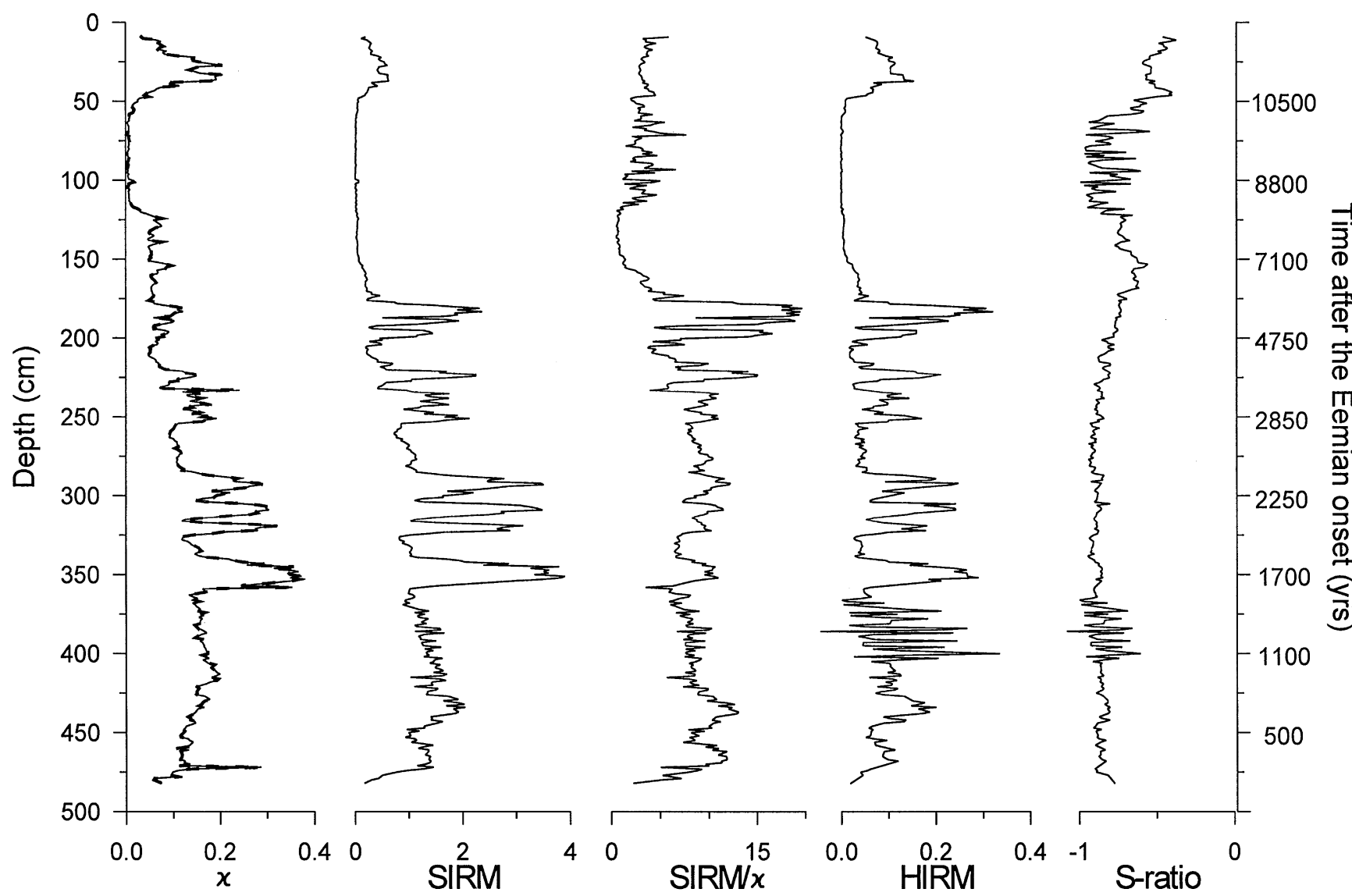

Fig. 14. Five mineral magnetic parameters, including the SIRM/susceptibility ratio $(\chi=$ magnetic susceptibility; SIRM $=$ saturation isothermal remanent magnetization; HIRM = high-field isothermal remanent magnetization), related to both depth and time. 
(1/s-ratio) on the aliphats and fatty acid methylesters. For the detailed theory behind such ratios see Meyers and Ishiwatari (1993). In short, the OEP ratio discloses the maturity of the material, its source and depositional environment. Dominance of odd chains among aliphats in the interval of chains $\mathrm{C} 25-\mathrm{C} 33$ suggests a terrestrial source, whereas dominance in the interval $\mathrm{C} 15-\mathrm{C} 17 \mathrm{im}$ plies limnic algae or bacteria. The closer the ratio comes to 1 the more mature is the material. Dominance of even chains mostly occur in anoxic, evaporitic or carbonate environments.

The ratio of long and short $(1 / \mathrm{s})$ chains can also be used to interpret the source material. As stated above, short chains such as $\mathrm{C} 17$ dominate in algae-rich material, while e.g. C27 and C29 suggest that the material comes from trees. C31 is typical for grasses and the spectrum C29-C33 is generally attributed to the waxy coating on leaves from higher plants. Short chains are also easier decomposed than the longer ones.

Our analyses show (Fig. 15) an increase in terrestrially derived organic material in the upper part of the analysed section. The high degree of maturity in the lower part may suggest high degree of decomposition/diagenesis, while the significantly less mature terrestrial organics in the top implies short transport before burial. This change in organic chemistry can be explained by changes in the lake hydrology: the lake may have experienced a waterlevel lowering, whereby the terrestrial vegetation came closer to the site, or increased precipitation caused soil erosion and increased inwash of terrestrially derived organic material. Sediments, magnetic mineral and diatom records show that the latter explanation is the most likely one.

\subsection{Correspondence analysis and zonation of the data set}

Correspondence analysis (CA) of 10 variables on 55 samples shows that the first two axes cover $87.6 \%$ of the total variance. Based on these two axes the section was divided into eight CA-zones (H1-H8), which have been related to the other main zonations (Fig. 16). High susceptibility, SIRM and HIRM values are, e.g. clearly anticorrelated with the lowest ${ }^{13} \mathrm{C}_{\text {org }}$ values as well as high $\mathrm{pH}$ and TOC values. High values of mineral matter (incl. diatoms) are anti-correlated with the carbonate content, and high percentages of planktonic diatoms are strongly correlated with highly negative S-ratios, i.e. dominance of magnetite grains. Negative values on the first axis thus relate to high input of magnetite particles, carbonate precipitation and abundance of planktonic diatoms. Positive values on the other hand are related to high content of mineral matter (mainly diatom opal) and TOC together with high $\mathrm{pH}$ and strongly negative ${ }^{13} \mathrm{C}_{\text {org }}$ values. The first CA-axis, reflecting $76.5 \%$ of the total variance, thus seems to reflect a productivity/lake level gradient. The second CA-axis $(11.5 \%$ of the variance) is strongly

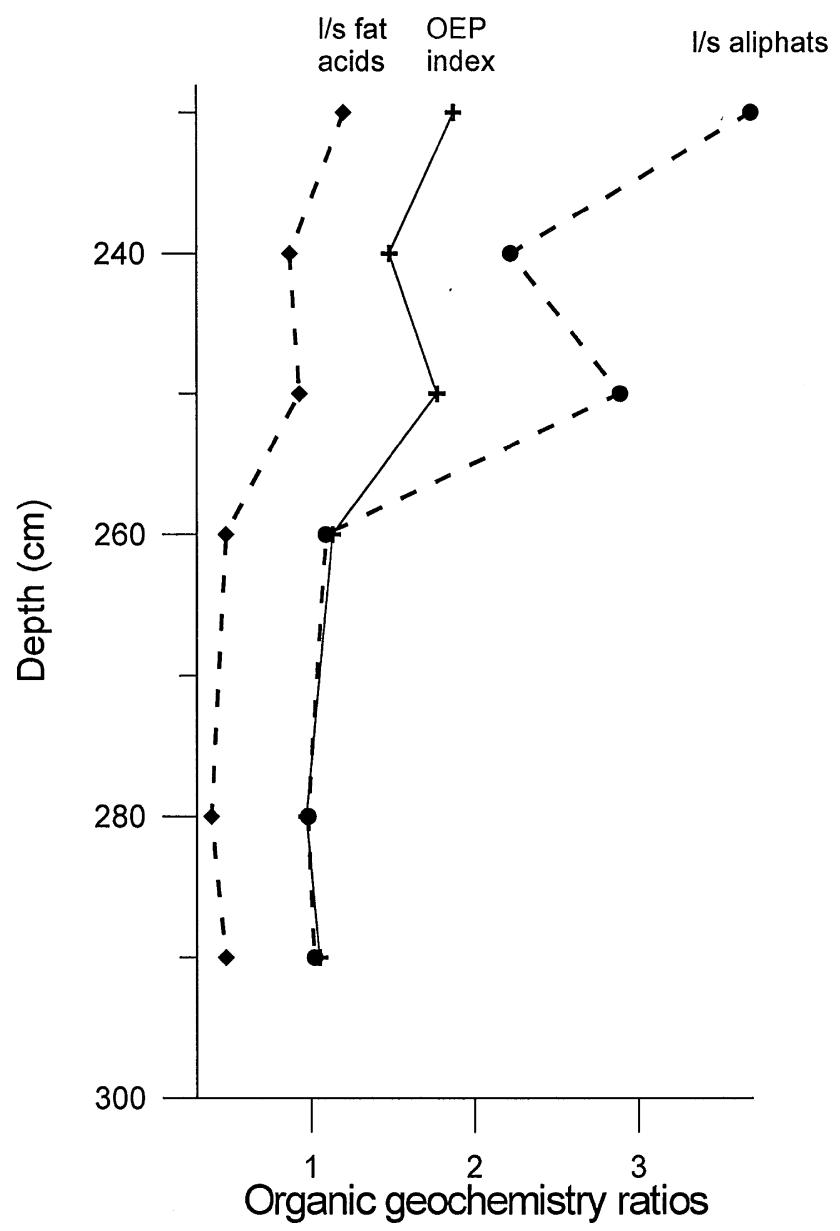

Fig. 15. Three organic geochemistry ratios before and during one of the SIRM and magnetic susceptibility peaks at $258-230 \mathrm{~cm}$ depth. OEP $=$ Odd $/$ Even Preference, $1=$ long, $\mathrm{s}=$ short .

related to the uppermost zone (H8) with its different interaction between variables.

\section{A paleolimnological and paleoclimatological synthesis}

The following description is subdivided into the eight CA-zones, since they represent the major part of the data set, but all presented data will be included in this synthesis. The lower- and uppermost facies associations will only be related to as pre-zone $\mathrm{H} 1$ and post-zone $\mathrm{H} 8$, respectively, since they were not analysed in the same manner as the rest of the section. In Fig. 16 this zonation is stratigraphically related to our diatom zones and Andersen's (1965) pollen zonation. This comparison both reveals many similarities as well as striking differences between the zonations, which suggests varying responses, including time lags, to external forcing mechansims, such as e.g. climatic/hydrologic changes. We have also transferred our lake level curve to Müllers (1974) Eemian 


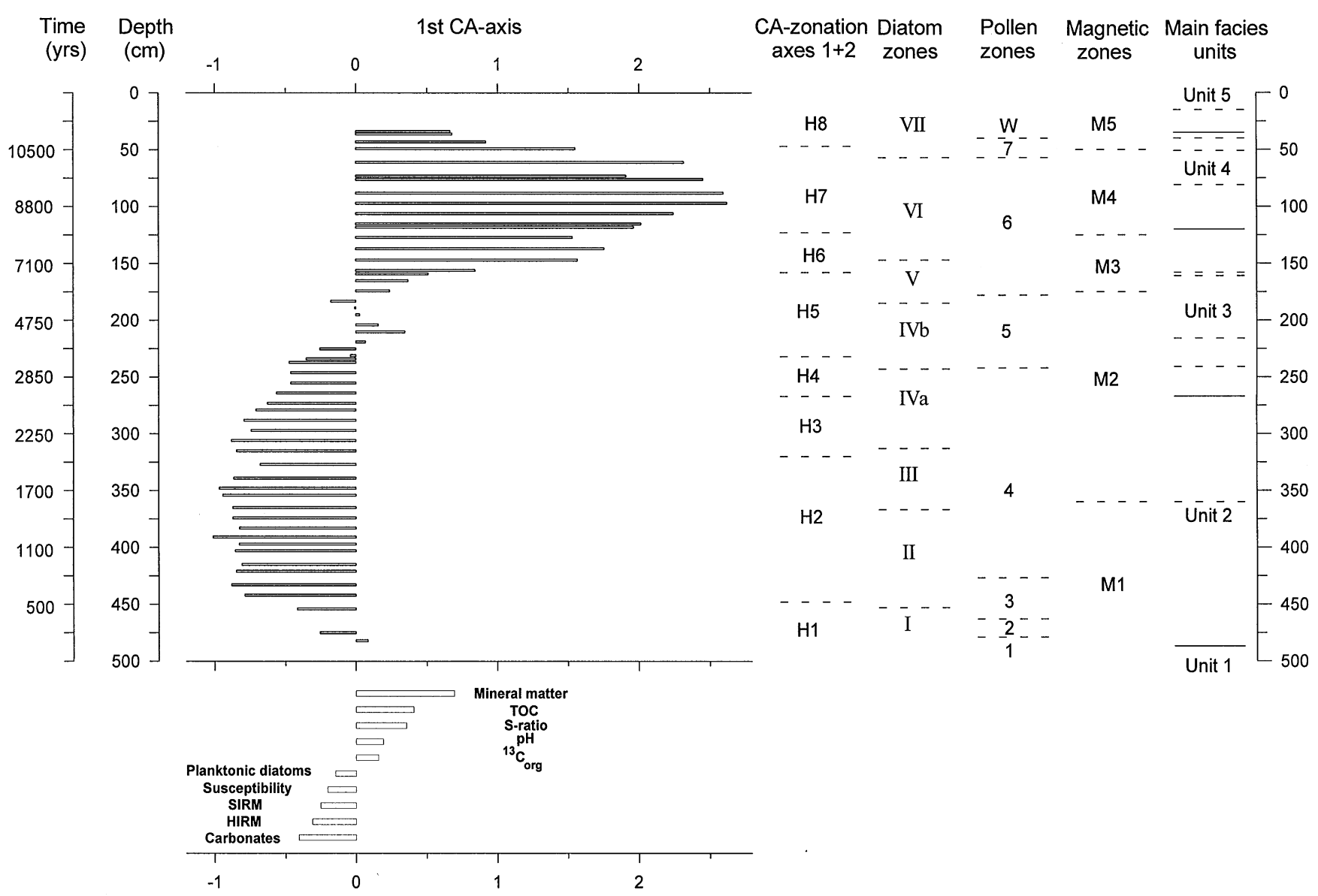

Fig. 16. Sample values (plotted as filled bars) of the first correspondence analysis (CA) axis ( $76.5 \%$ of the variance) on the 55 samples that were analysed with respect to the 10 variables (note that mineral matter includes diatom silica) plotted below (non-filled bars), related to both depth and time. The strength of the variables is shown in the same scale as the sample strength. High positive CA-values in the bar plot for S-ratio and ${ }^{13} \mathrm{C}_{\mathrm{org}}$ relate to low negative values and high negative per mil values, respectively. The CA zonation to the right of the first axis plot is based on the first two axes ( $87.6 \%$ of the variance). The CA zonation is also compared to subdivisions obtained from diatom and pollen assemblages, mineral magnetic properties and lithologic facies description. The latter is divided into the five main facies association units (full lines) and subunits (dashed lines). Note that the statistic values are related to a linear depth scale, which e.g. means that the first lake lowering $(275-255 \mathrm{~cm})$ with its high sedimentation rate is more gradually displayed, while the second one at $158-120 \mathrm{~cm}$ is very abrupt. Also note the gradual lake development and the oscillating pattern in the lower part.

chronology in Fig. 17, which results in a different pattern compared to the depth related curve (Fig. 7).

Pre-zone H1 (below $485 \mathrm{~cm}$ ). The two lowermost clastic facies associations display very different environments. The clastic material is probably of a glaciofluvial origin and the gravel may represent a lag in a filled up basin. Later an immature sparsely vegetated soil surface developed on top of the lag. The ironcrust was probably formed during this time, before the basin was flooded.

Zone HI $(485-448 \mathrm{~cm} ;-0.5 \mathrm{ka})$. All data presented suggest that this period was characterized by a rapid lake level rise. This zone covers pollen zones 1-2 and the beginning of zone 3 . The pollen assemblages show a rapid plant succession from a fairly open Betula and herb/shrub (Gramineae, Salix, Rumex) dominated vegetation to a half-open birch-pine forest mixed with some elm trees. The beginning of zone 3 is characterized by a very rapid increase of oak pollen and the pollen spectra suggest a vegetation mosaic consisting of Quercus, Pinus, Fraxinus, Ulmus and Betula mixed with some Juniperus and herbs. The forest was possibly still slightly open. It is impossible to deduce with certainty from our data whether the lake level rise is related to increased precipitation $(\mathrm{P})$ alternatively decreased evaporation (E) and/or a general rise in base level. The latter, caused by the early Eemian marine transgression (Zagwijn, 1983), lead to higher ground-water levels in coastal regions. This rapid transgression also resulted in an archipelagolike landscape with a maritime climate. The decline of a very short lasting pine forest phase, and its replacement by rapidly expanding decidous forest, may also have been triggered by increased maritime conditions, but may also have been part of a rapid, but natural forest succession. 


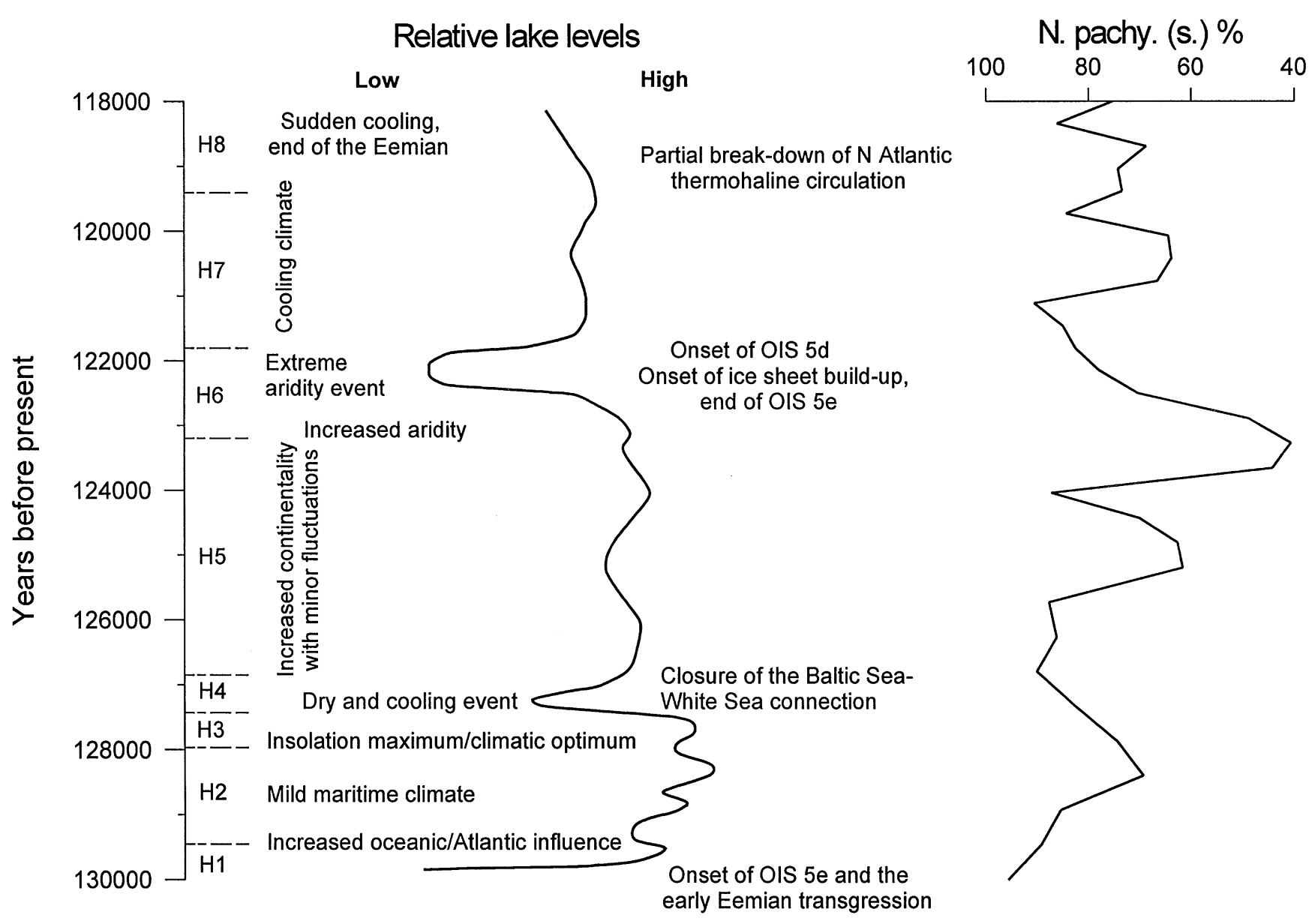

Fig. 17. Relative lake level changes in the Hollerup basin related to ka BP and the 8 CA-zones in Fig. 16. Climatic/hydrologic interpretations of the Hollerup record are shown to the left of the lake level curve, while inferred regional/global events are shown to the right of the curve. The basic assumptions behind the Hollerup chronology are twofold: the Eemian begins at $130 \mathrm{ka}$ BP (Martinson et al., 1987) and Müller's (1974) Eemian chronology is valid. The curve to the right shows Fronval and Jansen (1996) N. pachyderma (s.) record from core ODP 644 in the Norwegian Sea from the time interval 130-118 ka BP. Their chronology was created by correlation of oxygen isotopes to the SPECMAP chronology (Martinson et al., 1987).

Zone H2 (448-320 cm; 0.5-2.0 ka). This zone was characterized by high, but changing lake levels. Occasional high lake levels, indicated by, e.g. the susceptibility and planktonic diatom peaks, suggest $50-150 \mathrm{yr}$ long periods of high $\mathrm{P}: \mathrm{E}$ ratios. These periods of high precipitation/humidity seem to have been almost extreme events during a more long-term trend of a high lake level. The absence of a geomagnetic response in the lower part of the zone during peaks of planktonic diatoms is explained by the fact that a few thousand of years are needed before the pedogenic magnetite particles are formed in the catchment soils of areas with temperate-maritime climate (Maher, 1998). A small lag occurs between the planktonic diatom response and the geomagnetic signal. As would be expected, the diatom assemblage changes directly in response to a lake-level rise, while influx of soil derived particles cannot take place until maximum lake-level is reached and the soils around the rim of the lake are transgressed. The increased maritime conditions and the following rise in base level resulted in fairly warm and humid conditions with a rising groundwater level. Zone $\mathrm{H} 2$ is correlated with the main part of pollen zone 3 and the lower half of pollen zone 4 and these zones are dominated by Quercus, Pinus and Fraxinus pollen, and Corylus, Alnus, Taxus and Quercus pollen, respectively. This very dynamic vegetation succession over a short time, including the simultaneous rise and abundance of Taxus and Alnus, which both prefer fairly humid conditions, could have been favoured by the increased humidity inferred for this time period.

Zone H3 (320-267 cm; 2.0-2.7 ka). Lake level was still high with occasional and distinct high stands as described from the previous zone. In addition to the geomagnetic and planktonic diatom peaks, our organic geochemistry analyses clearly show that the organic matter in these peaks is to a large extent terrestrially derived. 
These high lake level pulses with soil erosion did, however, cease a few hundred years before the end of this period. This zone corresponds to the upper part of pollen zone 4, dominated by Corylus, Alnus, Quercus, Taxus and Ulmus pollen, but it is also the period with most abundance of Tilia pollen. The sediment records, together with the pollen assemblage of this part of pollen zone $4(700-650 \mathrm{~cm})$, seem to imply a warm and humid climate, which we, like e.g. Frenzel (1991), regard as the Eemian climatic optimum, at least with respect to mean annual temperature, while Menke (1981) and Menke and Tynni (1984) from studies in near-by SchleswigHolstein prolong this optimum phase through most of our zones $\mathrm{H} 4-\mathrm{H} 5$. In this context it is, however, worth mentioning that summer insolation at mid-high northern latitudes is supposed to have reached a maximum between 128 and $127 \mathrm{ka} \mathrm{BP}$ (Berger, 1978), and if the onset of the Eemian is placed at $130 \mathrm{ka}$ BP (Martinson et al., 1987), zone H3 would correspond to this insolation maximum period. Precipitation was possibly as high, or even higher, than previously, but higher evaporation, due to increased summer temperatures, may have decreased the $\mathrm{P}$ : E ratio slightly and thus also the lake level at the end of zone H3, as supported by e.g. diatom data.

Zone H4 (267-232 cm; 2.7-3.2 ka). The onset of this period is characterized by a distinct lake level fall, clearly documented by e.g. the diatom data and the sedimentology, followed by a rising lake level, but without reaching the previously highest levels. The lake level fall may suggest a period of increased influence from more continental air masses with a distinctly decreased $\mathrm{P}$ : E ratio. This scenario could imply shorter but warmer summers and longer and colder winters. It is also fascinating to speculate about the occurrence of the fallow deer during this event, and boldly assume that the animal drowned by walking on weak lake ice it must have occurred in September-October, since the calf was 2-4 months old. This implies that the lake was covered by ice in the fall, which, if it was not a very extreme event, would suggest that mean daily October temperatures were more than $5^{\circ} \mathrm{C}$ lower than today. From a vegetation viewpoint this corresponds to the sudden Picea rise slightly before the onset of pollen zone 5, the much debated Carpinus zone with its abundance of Carpinus, Picea, Alnus, Pteridium, and Betula pollen grains. Whether this vegetation change is related to acidification of soils, mainly triggered by the spread of spruce, or vice versa through a changing climate, is extremely difficult to conclude. However, it would be strange if this lake level fall by coincidence occurred at the same time as the vegetation so clearly changed character. Furthermore, the $\mathrm{pH}$ calibration and sediment geochemistry $\left(40 \% \mathrm{CaCO}_{3}\right)$ do not show any sign of acidification in the lake. On the other hand, one can argue that the possibly ground water fed lake always had highly buffered water, while the soils at the same time gradually acidified, a process which was enhanced by the sudden arrival of spruce. We think, however, there may be an indirect coupling between climate and the possible acidification processes. The former favoured the establishment of a partly new vegetation; a short period (some hundreds of years) of increased continental conditions favoured the expansion of spruce, which in turn lead to increased acidification of the top-soils. This may also have favoured the expansion of hornbeam at the expense of most of the mixed deciduous forest elements. In fact, the climax forest elements may already have suffered by the short phase of increased continental conditions that we postulate favoured the Picea expansion. It is also noteworthy that when Picea began to expand this event coincides with smaller expansions of, e.g. Gramineae and Rumex pollen.

Zone H5 $(232-158 \mathrm{~cm} ; 3.2-6.8 \mathrm{ka})$. This seems to be a long transition phase between carbonate rich sediments and the diatom dominated deposits. After the low stand in the beginning of the preceding zone and the following rise, the lake seems to have reached a new equilibrium, but at a lower level than during zones $\mathrm{H} 2$ and $\mathrm{H} 3$. Changes in the $\mathrm{P}$ : E balance did, however, produce some minor lake level fluctuations (Fig. 7). The highest lake levels during this period seem to have been reached at about $180 \mathrm{~cm}$, followed by a slowly falling level as shown by a slow but gradual fall in planktonic diatoms and the sudden absence of SIRM peaks. The end of the zone is also characterized by high phosphate loadings and rising $\mathrm{pH}$ values as inferred from the diatoms, as well as diatom taxa typical for wind-stressed environments, which taken together all may imply falling lake levels. This hydrologic change corresponds to the boundary between pollen zones 5 and 6, the latter dominated by Picea, Alnus, Betula and Pinus. Zone H5 corresponds to large parts of pollen zone 5 and the lower part of pollen zone 6, also characterized by increasing Quercus, Corylus and Gramineae pollen values. Summing up, these independent data sets suggest that the Carpinus zone was characterized by a fairly mild and humid climate resulting in medium-high lake levels with some minor oscillations. The slowly falling lake level after $180 \mathrm{~cm}(5.7 \mathrm{ka})$ may indicate gradually increased continentality and aridity, either as a result of a progressively changing climate or as an effect of a relative sea level fall. The latter lowers the local base level, which may effect the regional ground water level. The near-shore Tapes Sand deposits, considered to represent the Eemian regression in Denmark, cannot, however, be related to the Eemian pollen zones, and thus not to our data set. However, once again a hydrologically forced lake response coincides with a regional pollen stratigraphic boundary (zones 5/6). This may imply that climate was a trigger or reinforcer for all the changes revealed by our data. A generally more arid climate, in combination with the continued soil acidification, may explain the distinctly increasing abundance of 
pine pollen at the upper part of pollen zone 5 and beginning of pollen zone 6 .

Zone H6 (158-123 cm; 6.8-8.0 ka). According to all our lake sediment data, this zone possibly represents the most dramatic change in the lake's Eemian history. The falling lake level trend in the previous zone continued, but the rate of lake level fall increased considerably and a minimum was reached at the end of the zone, when the sediments were either subaerially exposed or bottomfrozen. This undoubtedly suggests a significant regional hydrologic change with low $\mathrm{P}: \mathrm{E}$ ratios and distinctly lower ground-water levels, probably caused by an external climatic forcing. We envisage a very small, shallow and highly productive lake, rich in organic matter, nutrients and salts (resulting in the high $\mathrm{pH}$ values). Part of the lake occasionally dried up in summer and occasionally froze to the bottom during winter. Fairly long periods of ice cover resulted in anaerobic conditions and our sulphide-rich sediments. This part of the lake's history clearly corresponds to $425-360 \mathrm{~cm}$ in the pollen diagram, when the pine pollen curve rises continuously and reaches a clear maximum, coinciding with short-lasting minima in e.g. Alnus, Picea and Taxus pollen. Combining all these independent data into a likely paleoclimatic scenario leads us to conclude that this period was characterized by gradually more arid conditions, ending up with a very low $\mathrm{P}$ : E ratio. The data may also imply that winters may have been fairly cold, while summers might have been fairly warm and dry. Such a continental climatic situation can explain all the characteristics of this zone, including the pollen signal. It is noteworthy, that once again a clear pollen signal coincides with a "lake signal". However, the pollen signal alone may also be interpreted in pure terms of vegetation succession, related to an ongoing soil acidification. In this context it should, however, be noted that the pollen spectrum after the pine peak partly resembles the spectrum before the peak, suggesting that the pine maximum is an anomaly in a normal succession. We conclude that this part of the Eemian in Denmark was characterized by increased continentality and that a nearly extreme climatic event, characterized by arid and possibly cool conditions, occurred during the last few hundred years of this period.

Zone H7 (123-55 cm; 8.0-10.3 ka). According to sedimentology, stable isotopes and the geomagnetic parameters the extreme conditions of the upper part of the preceding zone ended and were followed by a rising lake level. The complete dominance of benthic diatoms, high organic values and very high diatom inferred $\mathrm{pH}$ values do, however, show that it was only a small, shallow, highly productive, nutrient-rich lake. In general, lake levels were possibly similar to the levels in zone $\mathrm{H}$, but a smaller lake level rise may have occurred in the upper part of the zone, shown by e.g. a slight fining upwards trend in the sediments, rising planktonic diatom values and falling $\mathrm{pH}$ values. This period corresponds to pollen zone 6 above the pine maximum at $360 \mathrm{~cm}$, and it begins with declining and fairly low Pinus values, low and rising Betula values and slowly rising herb pollen values. A conspicious feature throughout the period is the inverse relationship between Pinus and Picea values, which may be an aridity/humidity signal, and which, e.g. shows a pine decline/spruce increase in the upper part of the zone where our lake data imply slightly rising lake levels. Apart from these smaller changes, the vegetation picture is rather stable and a fairly open mix of pine, spruce and birch dominated the acid soils of the uplands, while alder was an important component around lakes and in low-lying wetter areas. We envisage a fairly stable, slightly continental, cooling climate without any signs of extreme conditions regarding temperature or the $\mathrm{P}: \mathrm{E}$ ratio.

Zone H8 $(55-34 \mathrm{~cm} ; 10.3-11.0 \mathrm{ka})$. This period covers the uppermost CA-analysed samples, and, according to our correlations, represents the very end of the Eemian (Andersen, 1965), i.e. pollen zone 7. The lake data imply a lower lake level, increased inwash of clastic material from intensified soil erosion, including carbonates, and significantly decreased lake productivity. This suggests arid and colder conditions, which are also implied by the pollen assemblage of pollen zone 7 with its dominance of pine and birch pollen, together with still fairly high spruce and alder values, and rising values of Calluna and herb pollen. It should, however, be noted that the lake sediment data show that this transition into the Weichselian glacial was more gradual than some of the changes recorded during the main Eemian stages.

Post-zone H8 (34 to $-10 \mathrm{~cm} ; 11.0-$ ? ka). The cooling and possibly also arid trend described from the preceding period was interrupted by a sudden change at the Eemian/Weichselian boundary. The lake became shallow with low organic production, completely dominated by clastic input and surrounded by a much more open vegetation dominated by shrubs and herbs, but also with occasional stands of birch. For a while pine, spruce and alder may have persisted in the region, but soon the Weichselian cooling had created a birch-dominated park tundra. Occurrences of undoubtedly redeposited pollen grains, e.g. Corylus and Ilex, complement our picture of a period characterised by significant soil erosion. Finally, the former lake basin was filled by clastic sediments, originating from a cyclic, seasonal-dependent erosion of the gradually more unstable, barren soils as the previous temperate environment turned into a subarctic-arctic one.

\section{Regional correlations}

We interpret the data in terms of significant hydrologic changes in Denmark during the Eemian. There are no 
reasons to believe that such alterations in the hydrological balance are purely of local origin. The type of largescale hydrologic changes we see in our record (Fig. 17) were most likely driven by a combination of sea level changes and regional changes in weather patterns, in turn driven by atmospheric/oceanic circulation changes. Although our study can be regarded as almost unique, with its abundance of different proxy records and their high time resolution, we consider it likely that other northwest European/North Atlantic Sea Board Eemian records show a similar development, or can at least be interpreted to reflect a more variable climate than has been traditionally considered to characterise the Eemian. There are, however, some problems connected with such comparisons and correlations to other records: (1) The two most distinct mid-Eemian hydrologic changes found at Hollerup were fairly rapid, lasted only for a few hundred years and were followed by conditions not very dissimilar to the climate before the hydrologic event. Without a very detailed record they may thus be hard to detect, as have short-lived climatic events in the Holocene. (2) Most other detailed terrestrial Eemian studies have been based on pollen analyses. However, our study shows that, although the hydrologic events coincide with changes in vegetation the latter may also be explained in terms of natural vegetation succession and/or the development of soils (Andersen, 1965). (3) The time scale and dates for the majority, if not all, Eemian studies (including the ice cores) are very uncertain (cf. Winograd et al., 1997).

In spite of the above-mentioned problems we will try to compare our results to other Eemian studies and to evaluate differences and similarities between the records and the interpretations of these. When the GRIP Eemian record was first published (Dansgaard et al. 1993) it created a renewed general interest in Eemian climate development, and in particular in its degree of stability. The Field et al. (1994) climate reconstruction was mainly based on climate response surfaces of the pollen spectra from the two well-known Eemian sites Bispingen (Müller, 1974), and La Grand Pile (Woillard, 1978). They suggested that the last interglacial climate was significantly more unstable than the Holocene. The results from Bispingen, with the same chronology as we have adopted, show two marked climatic changes with increased aridity/continentality, and a very distinct cooling event inbetween. Based on pollen- (and chrono-)stratigraphy, the two marked climatic changes occurred approximately when the Hollerup sediments also display the two hydrologic events. On the other hand, there are no traces of the very distinct cooling in our records during the Carpinus pollen zone. It is unlikely that a period with a central Siberian winter climate (cf. Field et al., 1994) would not be identified by our dense proxy records, and we are therefore sceptical about the occurrence of any such extreme Eemian cooling event. In addition, our data does not concur with Field et al. (1994) continuously low mean winter temperatures $(-5$ to $10^{\circ} \mathrm{C}$ ) during the last $7000-8000 \mathrm{yr}$ of the Eemian. The more southerly situated La Grand Pile site shows considerably more subtle changes, which may imply a strong north-south climatic gradient during our hydrologic events. The Thouveny et al. (1994) magneto- and pollenstratigraphic study of Lac du Bouchet in the Massif Central shows some fairly large changes during the course of the Eemian, but the climatic significance of the recorded changes is not clear, and the pollen- and chronostratigraphy is not comparable to the Bispingen and Hollerup sites. We therefore avoid comparison with Lac $\mathrm{du}$ Bouchet. The Litt et al. (1996) review on central German Eemian sites, together with several other recent Eemian studies (e.g. Frenzel, 1991; Zagwijn, 1996) contrasts with the supposedly unstable Eemian scenarios. Based on the climate indicator species approach, they argue that the Carpinus phase was not characterised by low winter temperatures. However, they do not discuss the possibility of two hydrologic events, preceding and following the Carpinus phase. These events are indicated by the Field et al. (1994) evapotranspiration curve, which is based on the pollen spectrum, and they are also indicated by our sediment records. There is obviously the possibility that these different "schools of thought" on the Eemian development may be united into a more holistic picture.

We find it difficult to make a direct comparison to the GRIP data (Dansgaard, 1993), due to the different time scales. The GRIP ${ }^{18} \mathrm{O}$ data suggest that the Eemian is more than 15,000 yr long, and the existence of a $6000 \mathrm{yr}$ long first cooling (stage 5e4). The onset of this cold period may, theoretically speaking, correspond to our first hydrologic event, without any return to the previous condition until several thousand year later. Our second hydrologic event could then correspond to the short, but distinct, $5 \mathrm{e} 2$ event in GRIP. However, all such correlations remain speculative until a more secure Eemian record is recovered from the Greenland ice.

Another interesting set of data comes from North Atlantic marine cores. While the central North Atlantic cores seem to exhibit fairly stable Eemian conditions (McManus, 1994; Cortijo, 1994), the picture changes when marine cores in Denmark, between Norway and Greenland (the GIN seas) or in the Labrador Sea are taken into consideration. The Danish records from Nørre Lyngby and Skagen 3 (Seidenkrantz et al., 1995; Seidenkrantz and Knudsen, 1997) show two distinct periods of decreased water temperature and changes in ocean circulation, preceded and followed by slightly warmer than present conditions. The authors relate these events to phases of a weakened North Atlantic Drift, which would allow arctic water to spread further south. This would cause water mass changes and a southward displacement of faunas, shown by clear shifts in the stable isotope 
values and distinct faunal changes, respectively. Without good pollen spectra the timing of these events, in relation to the lacustrine sites, is difficult to assess. However, if a continuous Eemian sedimentation rate is assumed for the Skagen 3 core and the length of the interglacial is the same as we have adopted, the first cooling occurs c. $4000 \mathrm{yr}$ into the interglacial and the second event happens c. $8000 \mathrm{yr}$ after the onset of the Eemian. The latter age is the same as we have concluded from Hollerup, while the first event is $1000 \mathrm{yr}$ older in Hollerup (based on this rough calculation). Fronval and Jansen (1996) data from the GIN seas (Fig. 17) show three main coolings, dated to $127-126,122-121$, and $117 \mathrm{ka}$, of which the last one could represent the transition to the Weichselian. The dates of the two first events do, however, correspond almost perfectly to the two large hydrologic events in Hollerup, which is actually also the case with two similar events in the Labrador Sea (Seidenkrantz et al., 1995). It is also noteworthy that Adkins et al. (1997) detailed marine record from the Bermuda Rise shows an Eemian with some variability during the first $8000 \mathrm{yr}$, followed by a distinct change in deep-water flow, occurring over $400 \mathrm{yr}$, which gradually lead into OIS $5 \mathrm{~d}$. This abrupt change, documented by benthic $\mathrm{Cd} / \mathrm{Ca} \mathrm{ra}-$ tios and planktonic and benthic $\delta^{18} \mathrm{O}$ values, could correspond to the largest change we see in our record, the abrupt lake level lowering at $122 \mathrm{ka}$, which also seems to have been followed by a gradually deteriorating climate that finally ended the Eemian interglacial climate. In this context it should be noted that the McManus et al. (1994) planktonic foraminifera and IRD records show that North Atlantic surface water remained fairly warm and without glacial impact, while the ${ }^{18} \mathrm{O}$ record of their benthic foraminifera, upon which the marine isotope stratigraphy is based (Martinson et al., 1987), show that glaciation had already begun. This suggests that OIS 5e is not the marine equivalent to the terrestrial Eemian (cf. Kukla et al., 1997; Broecker, 1998), but that the terrestrial Eemian corresponds to OIS 5e and several milennia of OIS $5 \mathrm{~d}$.

\section{A possible Eemian synthesis}

We see no reason to reject the idea of a partly unstable Eemian in NW Europe. Many of the studies cited above find clear indications of significant, but short-lived, anomalous climatic events. The climatic picture that most clearly emerges when these records are compared, is that a fairly good agreement exists between our data and the marine regions that are sensitive to circulation changes in the Nordic Seas or changes in the heat and water exchange between the North Sea and the Baltic Sea. Below we will try to give a picture of the course of events that may have triggered the changes we see in our Hollerup section (Fig. 17).
The initial, very distinct lake level rise can at least partly be explained by the regional Saalian-Eemian relative sea level history. The lack of late glacial Saalian lake sediments suggests that no prerequisites existed for a lake basin to form, and this may be related to an extremely low groundwater level. When the forebulge of the retreating, formerly very extensive Saalian ice sheet moved northwards through Jylland, it must have resulted in very low relative sea levels (cf. the so-called regression maximum in S Scandinavia following the Late Weichselian deglaciation) until the eustatic rise finally became greater than the glacial isostatic rebound. In a combination with arid conditions, possibly caused by the high-pressure cell over the retreating Saalian ice sheet in the north, the lack of water in the Hollerup basin until the very beginning of the Eemian can be explained. However, when the Baltic Sea-White Sea threshold opened, as a consequence of the deglaciation of this area, and relative sea level began to rise in the Danish area, a completely new situation was created. This resulted in rising base level/regional groundwater as well as a more maritime-influenced climate. The latter was a consequence of both the rising sea around Denmark, turning a previously land area into an archipelago with the effect of warmer Atlantic water protruding into the Baltic and northwards as a side branch of the North Atlantic Current. As a combined effect of these two processes Jylland became a large island in a fairly warm sea, and probably to a larger extent than today influenced by the low pressure systems from the west. A comparable modern analogue to Denmark's paleogeographic/paleoclimatic situation in the early Eemian would probably be Ireland or England.

As a consequence of the ongoing isostatic uplift in Karelia, the Baltic Sea-White Sea threshold was uplifted above sea level, closing the Baltic branch of the North Atlantic Current. This may have terminated the maritime "island effect" discussed above resulting in an increased influence of continental air-masses. We argue that this change may have triggered our first distinct lake level lowering at $127 \mathrm{ka}$. The following long, fairly stable period with increased continentality is an expression of a new equilibrium in the hydrologic cycle, which was interrupted by the dramatic lake level lowering at $122 \mathrm{ka}$. It is possible, based on the marine records discussed above, that this lake level lowering is the terrestrial equivalent to Adkins et al. (1997) first sign of changed deep-water flow and the McManus et al. (1994) termination of OIS 5e. This regional change in the hydrologic cycle, including a lower base level as ice sheets began to build up, may have lead into the final Eemian climatic/hydrologic mode resulting in a slightly cooler, and possibly more arid climate. These conditions seem to have remained approximately the same for a few millennia (possibly corresponding to parts of OIS 5d) until the North Atlantic thermohaline circulation suddenly broke down as an effect of increased glacial influence along the North 
Atlantic rim as the continental ice sheets kept expanding. The very sudden termination of the Eemian is seen in both our multi-proxy record and several pollen studies (e.g. Andersen, 1965; Müller, 1974; Woillard, 1978).

\section{Acknowledgements}

S. Th. Andersen is greatly acknowledged for giving us complete access to his pollen data set and allowing us to publish it and T. Fronval is thanked for giving us access to his complete marine data set. Sheri Fritz is thanked for discussions concerning diatom interpretations. Barbara Wohlfarth carefully read the manuscript, Birthe Warming carried out the isotope analyses, Andreas Sandgren and Per Sandgren carried out many of the mineral magnetic analyses, Uffe Wilkens carried out the organic geochemical analyses, Lisa Jacobsen, Mikhala D. Nielsen, Mikkel Sander and Niels Hansen carried out the geochemical analyses and the latter also constructed the TILIA drawn pollen diagram. For this help we are very grateful. We are also grateful to the two referees, D. Keen and J. Ehlers, for several constructive and clarifying amendments in the text. The study was financed by the Danish Science Research Council (SNF).

\section{References}

Adkins, J.F., Boyle, E.A., Keigwin, L., Cortijo, E., 1997. Variability of the North Atlantic thermohaline circulation during the last interglacial period. Nature 390, 154-156.

Andersen, S.T., 1965. Interglacialer og interstadialer i Danmarks kvartær. Meddelelser fra Dansk Geologisk Forening 15 (4), 486-506.

Andersen, S.T., 1966. Interglacial vegetational succession and lake development in Denmark. The Paleobotanist 15, 117-127.

Battarbee, R.W., 1986. Diatom analysis. In: Berglund, B.E. (Ed.), Handbook of holocene palaeoecology and palaeohydrology. Wiley, New York, pp. 527-570.

Bennion, H., 1994. A diatom transfer function for shallow, eutrophic ponds in southeast England. Hydrobiologica 275/276, 391-410.

Berger, A.L., 1978. Long-term variations of caloric insolation resulting from the earth's orbital elements. Quaternary Research 9, 139-167.

Birks, H.J.B., Line, J.M., Juggins, S., Stevenson, A.C., ter Braak, C.J.F. 1990. Diatoms and $\mathrm{pH}$ reconstruction. Philosophical Transactions of the Royal Society of London B 327, 263-278.

Broecker, W.S., 1998. The end of the present interglacial: How and when?. Quaternary Science Reviews 17, 689-694.

Buchardt, B., 1977. Oxygen isotope ratios from shell material from the Danish Middle Paleocene (Selandian) deposits and their interpretation as paleotemperature indicators. Palaeogeography, Palaeoclimatology, Palaeoecology 22, 209-230.

Cortijo, E.J., Duplessy, J.C., Labeyrie, L., Leclaire, H., Duprat, J., van Weering, T.C.E., 1994. Eemian cooling in the Norwegian Sea and North Atlantic Ocean preceding continental ice-sheet growth. Nature 372, 446-449.

Craig, H., 1957. Isotopic standards for carbon and oxygen and correction factors for mass-spectrometric analysis of carbon dioxide. Geochimica et Cosmochimica Acta 12, 133-149.
Dansgaard, W., Johnsen, S.J., Clausen, H.B., Dahl-Jensen, D., Gundestrup, N.S., Hammer, C.U., Hvidberg, C.S., Steffensen, J.P., Sveinbjörnsdottir, A.E., Jouzel, J., Bond, G., 1993. Evidence for general instability of past climate from a $250-\mathrm{kyr}$ ice-core record. Nature 364, 218-220.

DGU 1991. DGU Kortserie Nr. 32, Geologisk Basisdata kort 1215 II Bjerringbro.

Field, M.H., Huntley, B., Müller, H., 1994. Eemian climate fluctuations observed in a European pollen record. Nature 371, 779-783.

Frenzel, B., 1991. Das Klima des letzten Interglazials in Europa. In: Frenzel, B. (Ed.), Klimageschichtliche Probleme der letzten 130.000 Jahre. Paläoklimaforschung, Vol. 1. Stuttgart: Gustav Fischer, Shuttgart, pp. 51-78.

Fritz, S.C., Kingston, J.C., Engstrøm, D.R., 1993. Quantitative trophic reconstruction from sedimentary diaton assemblages: A cautionary tale. Freshwater Biology 30, 1-23.

Fronval, T., Jansen, E., 1996. Rapid changes in ocean circulation and heat flux in the Nordic Seas during the last interglacial period. Nature 383, 806-810.

Fronval, T., Jansen, E., 1997. Eemian and early Weichselian (140-60 ka) paleoceanography and paleoclimate in the Nordic seas with comparisons to Holocene conditions. Paleoceanography 12, 443-462.

Hartz, N., Østrup, E., 1899. Danske diatome aflejringer og deres diatomeer. Danmarks Geologiske Undersøgelser II 9, 1-80.

Håkansson, S., 1993. Numerical methods for the inference of $\mathrm{pH}$ variations in mesotrophic and eutrophic lakes in southern Sweden -A progress report. Freshwater Biology 30, 1-23.

Israelson, C., Björck, S., Hawkesworth, C.J., Noe-Nygaard, N., 1998. Uranium-series isotopes from Eemian lake deposits Hollerup, Denmark. Bulletin Geological Society of Denmark 44, 73-179.

Jessen, K., Milthers, V., 1928. Interglacial fresh-water deposits in Jutland and Northwest Germany. Danmarks Geologiske Undersøgelser II 48, 1-379.

Kelts, K., Hsü, K.J., 1978. Freshwater carbonate sedimentation. In: Lerman, A. (Ed.), Lakes: Chemistry, Geology, Physics. Springer, New York, pp. 259-323.

Kelts, K., Talbot, M., 1990. Lacustrine carbonates as geochemical archives of environmental changes and biotic/abiotic interactions. In: Tilzer, M.M., Serruya, C. (Eds.), Ecological Structure and Function. Springer, Berlin, pp. 288-313.

Kronborg, C., Bender, H., Bjerre, R., Friborg, R., Jacobsen, H.O., Kristiansen, L., Rasmussen, P., Sørensen, P., Larsen, G., 1990. Glacial stratigraphy of East and Central Jutland. Boreas 19, 273-287.

Kronborg, C., Mejdahl, V., 1989. Thermoluminescence dating of Eemian and Early Weichselian deposits in Denmark. Quaternary International 3/4, 93-99.

Kukla, G., McManus, J.F., Rousseau, D.-D., Chuine, I., 1997. How long and stable was the last interglacial?. Quaternary Science Reviews 16, $1-10$.

Litt, T., Junge, F.W., Böttger, T., 1996. Climate during the Eemian in north-central Europe - a critical review of the palaeobotanical and stable isotope data from central Germany. Vegetation History and Archaeobotany 5, 247-256.

Maher, B.A., 1998. Magnetic properties of modern soils and Quaternary loessic paleosols: Paleoclimatic implications. Palaeogeography, Palaeoclimatology, Palaeoecology 137, 25-54.

Martinson, D.G., Pisias, N.G., Hays, J.D., Imbrie, J., Moore, T.C., Shackleton, N.J., 1987. Age dating and orbital theory of the Ice Ages: Development of a high-resolution 0 to 300,000 year chronostratigraphy. Quaternary Research 27, 1-29.

McKenzie, J.A., 1985. Carbon isotopes and productivity in the lacustrine and marine environment. In: Sturm, W. (Ed.), Chemical processes in lakes. Wiley, New York, pp. 99-118.

McManus, J.F., Bond, G.C., Broecker, W.S., Johnsen, S., Labeyrie, L., Higgins, S., 1994. High- resolution climate records from the North Atlantic during the last interglacial. Nature 371, 326-329. 
Mejdahl, V., Funder, S., 1994. Luminescence dating of Late Quaternary sediments from East Greenland. Boreas 23, 523-536.

Menke, B., 1981. Vegetation, Klima und Verwitterung im Eem-Interglazial und Weichsel-Frühglazial Schleswig-Holsteins. Verhandlungen des Naturwissenschaftlichen Vereins in Hamburg (NF) 24 (2), 123-132.

Menke, B., Tynni, R., 1984. Das Eeminterglazial und das Weichselfrühglazial von Rederstall/Dithmarschen und ihre Bedeutung für die mitteleuropäische Jungpleistozän- Gliederung. Geologisches Jahrbuch A 76, 120.

Meyers, P.A., Ishiwatari, R., 1993. Lacustrine organic geochemistry - an overview of indicators of organic-matter sources and diagenesis in lake-sediments. Organic Geochemistry 20 (7), 867-900.

Møhl-Hansen, U., 1954. Første sikre spor af mennesker fra interglacialtid i Danmark. Aarbog for nordisk Oldkyndighed og Historie 154, 101-126.

Müller, H., 1974. Pollenanalytische Untersuchungen und Jahresschichtenzählungen an der Eemzeitlichen Kieselgur von Bispingen/Luhe. Geologisches Jahrbuch A 21, 149-169.

Noe-Nygaard, N., 1990. Man made trace fossil on bones. Journal of Physical Anthropology, Human evolution 4, 461-491.

Noe-Nygaard, N., 1995. A dynamic model for changes in palaeoclimate, environment and ecology in Late and Postglacial time, Sjælland Denmark. A multidisciplinary study. Fossil and Strata 37, $1-437$.

Oldfield, F., 1994. Towards the discrimination of fine grained ferrimagnets by magnetic measurements in lake and near-shore marine sediments. Journal of Geophysical Research 99, 9045-9050.

Potter, D.H., Stephenson, A., 1986. The detection of fine particles of magnetite using anhysteretic and rotational remanent magnetization. Geophyscial Journal of the Royal Astronomical Society 87, 569-582.

Reavie, E.D., Hall, R.I., Smol, J.P., 1995. An expanded weightedaveraging model for phosphorus concentration from diatom assemblages in eutrophic British Columbia (Canada) lakes. Journal of Palaeolimnology 14, 49-67.

Seidenkrantz, M.-S., Kristensen, P., Knudsen, K.L., 1995. Marine evidence for climatic instability during the last interglacial in shelf records from northwest Europe. Journal of Quaternary Science 10, $77-82$.

Seidenkrantz, M.-S., Knudsen, K.L., 1997. Eemian climatic and hydrographical instability on a marine shelf in Northern Denmark. Quaternary Research 47, 218-234.
Sejrup, H.-P., Haflidason, H., Kristensen, D.K., Johnsen, S.J., 1995. Last interglacial and Holocene climatic development in the Norwegian Sea region: Ocean front movements and ice-core data. Journal of Quaternary Science 10, 385-390.

Snowball, I.F., 1997. The detection of single-domain greigite $\left(\mathrm{Fe}_{3} \mathrm{~S}_{4}\right)$ using rotational remanent magnetization (RRM) and the effective gyro field (Bg): Mineral magnetic and paleomagnetic applications. Geophysical Journal International 130, 704-716.

Surlyk, F., Noe-Nygaard, N., Dam, G., 1993. High and low resolution sequence stratigraphy in lithological prediction - examples from the Mesozoic around the northern North Atlantic. In: Parker, J.R. (Ed.), Petroleum geology of Northwest Europe. The Geological Society, London, pp. 199-214.

Talbot, M.R., 1990. A review of the palaeohydrological interpretation of carbon and oxygen isotopic ratios in primary lacustrine carbonates. Chemical Geology (Isotope Geoscience Section) 80, 261-279.

Talbot, M., 1994. Sequence stratigraphy in lakes: The ups and down of small seas or something else. The 14th International Sedimentological Congress. Abstracts, pp. 68-69.

Ter Braak, C.J.F., 1988. CANOCO - a FORTRAN programme for canonical community ordination by [partial] [detrended] [canonical] correspondence analysis, principal component analysis and redundancy analysis (version 2.1). Technical Report LWA-88-02, Wageningen, Nerherlands. 95p.

Thouveny, N., de Beaulieu, J.-L., Bonifay, E., Creer, K.M., Guiot, J., Icole, M., Johnsen, S., Jouzel, J., Reille, M., Williams, T., Williamson, D., 1994. Climate variations in Europe over the past $140 \mathrm{kyr}$ deduced from rock magnetism. Nature 371, 503-506.

Troels-Smith, J., 1955. Characterization of unconsolidated sediments. Danmarks Geologiske Undersøgelser IV (3), 1-73.

Weimer, P., Krystinik, L., 1991. Significance of key surfaces in sequence stratigraphy. A working document presented to delegates of the Nuna Conference on High Resolution Sequence Stratigraphy. Banff, Alberta, Canada.

Winograd, I.J., Landwehr, J.M., Ludwig, K.R., Coplen, T.B., Riggs, A.C., 1997. Duration and structure of the past four interglacials. Quaternary Research 48, 141-154.

Woillard, G.M., 1978. Grande Pile peat bog: A continuous pollen record from the last 140.000 years. Quaternary Research 9, 1-21.

Zagwijn, W.H., 1983. Sea level changes in the Netherlands during the Eemian. Geologie en Mijnbouw 62, 437-450.

Zagwijn, W.H., 1996. An analysis of Eemian climate in Western and Central Europe. Quaternary Science Reviews 15, 451-469. 

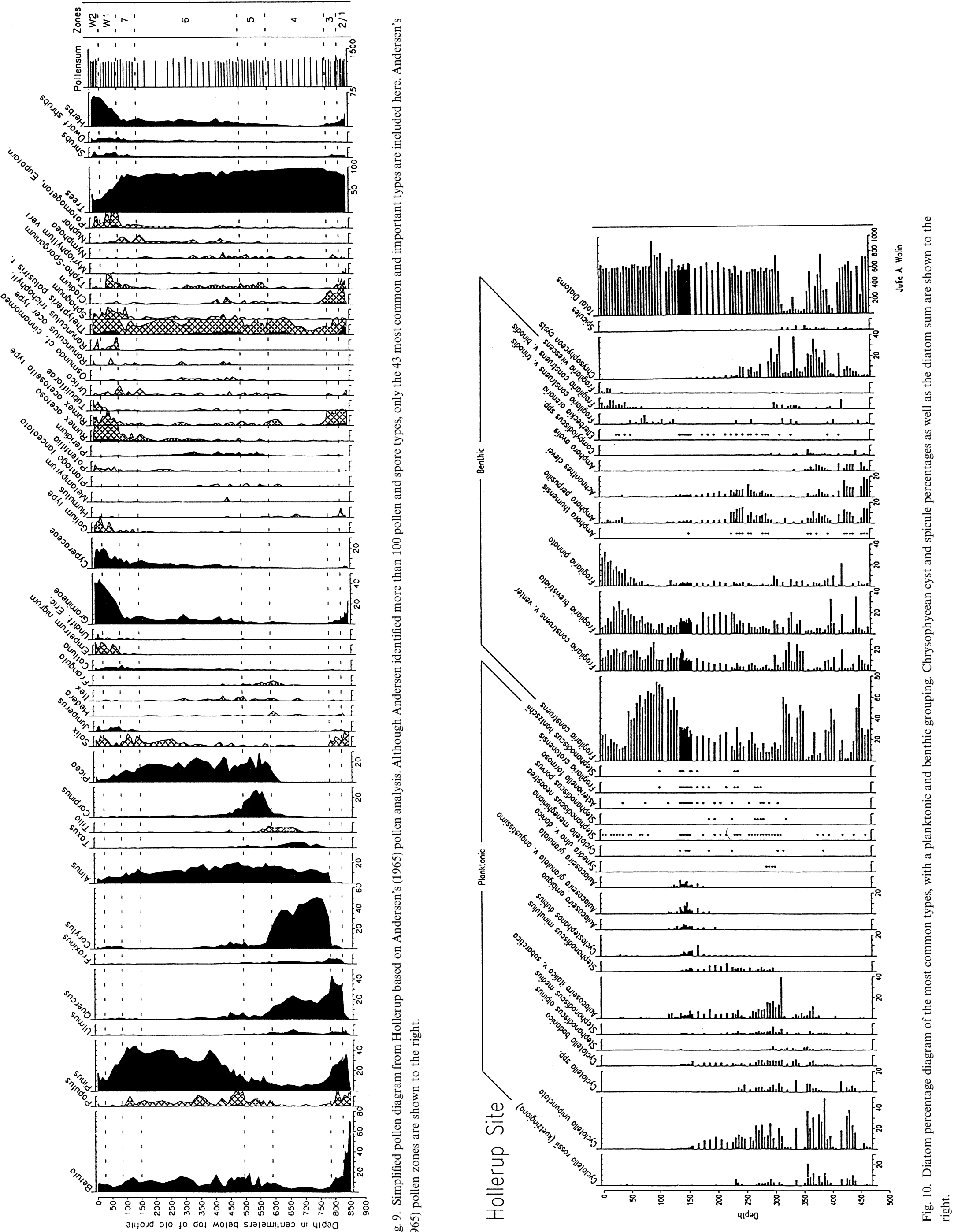